University of Wollongong

Research Online

Faculty of Engineering and Information

Sciences - Papers: Part A

Faculty of Engineering and Information

Sciences

$1-1-2014$

\title{
Enhancement of trace organic contaminant degradation by crude enzyme extract from Trametes versicolor culture: Effect of mediator type and concentration
}

\author{
Ngoc Luong Nguyen \\ University of Wollongong, Inn909@uowmail.edu.au \\ Faisal Ibney Hai \\ University of Wollongong, faisal@uow.edu.au \\ Jinguo Kang \\ University of Wollongong, jkang@uow.edu.au \\ Frederic Leusch \\ Griffith University \\ Felicity Roddick \\ RMIT University
}

See next page for additional authors

Follow this and additional works at: https://ro.uow.edu.au/eispapers

Part of the Engineering Commons, and the Science and Technology Studies Commons

Research Online is the open access institutional repository for the University of Wollongong. For further information contact the UOW Library: research-pubs@uow.edu.au 


\title{
Enhancement of trace organic contaminant degradation by crude enzyme extract from Trametes versicolor culture: Effect of mediator type and concentration
}

\begin{abstract}
The performance of two redox mediating compounds, namely 1-hydroxybenzotriazole (HBT) and syringaldehyde (SA), was compared in terms of enhancement of enzymatic degradation of a diverse set of 14 phenolic and 16 non-phenolic trace organic contaminants (TrOCs) and the toxicity of the treated media. Extracellular enzyme extract (predominantly containing laccase) from Trametes versicolor culture achieved efficient degradation (70-95\%) of nine phenolic and one non-phenolic TrOCs. Mediator dosing extended the spectrum of efficiently degraded TrOCs to 13 phenolic and three non-phenolic compounds, with moderate improvements in removal of a few other non-phenolic compounds. TrOC removal efficiency improved significantly as the HBT dose was increased from 0.1 to $0.5 \mathrm{mM}$, while SA achieved similar removal over dosage range of 0.1-1 mM. A particular concern was the toxicity of the treated media (1200-2200 times that of the control) for all SA dosages applied. Overall, HBT at a concentration of 0.5 $\mathrm{mM}$ achieved the best removal without raising concern regarding toxicity of the treated media. The results are discussed in the light of the redox potential of the enzyme-mediator cocktail, the balance between the stability and reactivity of the radicals generated and their cytotoxic effects.
\end{abstract}

\section{Keywords}

trametes, versicolor, culture, effect, mediator, degradation, type, crude, concentration, contaminant, organic, trace, enhancement, enzyme, extract

\section{Disciplines \\ Engineering | Science and Technology Studies}

\section{Publication Details}

Nguyen, L., Hai, F. I., Kang, J., Leusch, F., Roddick, F., Magram, S. Faraj., Price, W. E. \& Nghiem, L. D. (2014). Enhancement of trace organic contaminant degradation by crude enzyme extract from Trametes versicolor culture: Effect of mediator type and concentration. Journal of the Taiwan Institute of Chemical Engineers, 45 (4), 1855-1862.

\section{Authors}

Ngoc Luong Nguyen, Faisal Ibney Hai, Jinguo Kang, Frederic Leusch, Felicity Roddick, S Faraj Magram, William Price, and Long Nghiem 


\section{Enhancement of trace organic contaminant degradation by crude enzyme extract from Trametes versicolor culture: Effect of mediator type and concentration}

\section{Journal of the Taiwan Institute of Chemical Engineers 45 (2014) - 1855-1862}

Luong N. Nguyen ${ }^{\text {a }}$, Faisal I. Hai ${ }^{a^{*}}$, Jinguo Kang ${ }^{b}$, Frederic D. L. Leusch ${ }^{c}$, Felicity Roddick ${ }^{d}$, Saleh F. Magram ${ }^{e}$,William E. Price ${ }^{\mathrm{b}}$, and Long D. Nghiem ${ }^{\mathrm{a}}$

${ }^{a}$ Strategic Water Infrastructure Laboratory, School of Civil, Mining and Environmental Engineering, University of Wollongong, Wollongong, NSW 2522, Australia

${ }^{\mathrm{b}}$ Strategic Water Infrastructure Laboratory, School of Chemistry, University of Wollongong, Wollongong, NSW 2522, Australia

${ }^{\mathrm{c}}$ Smart Water Research Centre, School of Environment, Griffith University, Southport, QLD 4222, Australia

${ }^{\mathrm{d}}$ School of Civil, Environmental and Chemical Engineering, RMIT University, Melbourne, Victoria 3001, Australia

${ }^{\mathrm{e}}$ Department of Civil Engineering, King Abdul Aziz University, Jeddah 21589, Saudi Arabia

* Corresponding author: Faisal I. Hai, Email: faisal@uow.edu.au; Ph: +61 242213054 


\section{Highlights}

- Enzyme extract degraded all phenolic TrOC without electron withdrawing groups

- Unlike other non-phenolic TrOC, diclofenac removal by enzyme extract was high

- Despite similar reaction routes 1-hydroxybenzotriazole outperformed syringaldehyde

- Syringaldehyde performance did not improve beyond a dosage of $0.1 \mathrm{mM}$

- All dosages of syringaldehyde led to increased toxicity of the treated media 


\begin{abstract}
:
The performance of two redox mediating compounds, namely 1-hydroxybenzotriazole (HBT) and syringaldehyde (SA) was compared in terms of enhancement of enzymatic degradation of a diverse set of 14 phenolic and 16 non-phenolic trace organic contaminants (TrOCs) and the toxicity of the treated media. Extracellular enzyme extract (predominantly containing laccase) from Trametes versicolor culture achieved efficient degradation (70-95\%) of nine phenolic and one non-phenolic TrOCs. Mediator dosing extended the spectrum of efficiently degraded TrOCs to 13 phenolic and three nonphenolic compounds, with moderate improvements in removal of a few other non-phenolic compounds. TrOC removal efficiency improved significantly as the HBT dose was increased from 0.1 to $0.5 \mathrm{mM}$, while SA achieved similar removal over dosage range of 0.1 to $1 \mathrm{mM}$. A particular concern was the toxicity of the treated media (1200 to 2200 times that of control) for all SA dosages applied. Overall, HBT at a concentration of $0.5 \mathrm{mM}$ achieved the best removal without raising concern regarding toxicity of the treated media. The results are discussed in the light of the redox potential of the enzymemediator cocktail, the balance between the stability and reactivity of the radicals generated and their cytotoxic effects.
\end{abstract}

Keywords: Trace organic contaminants (TrOC); crude enzyme extract; laccase; mediator; 1hydroxybenzotriazole; syringaldehyde 


\section{Introduction}

The occurrence of trace organic contaminants (TrOCs) such as pharmaceuticals and personal care products, pesticides, steroid hormones and industrial chemicals in water and wastewater is of increasing concern. Many TrOCs have been implicated in endocrine disrupting effects on aquatic organisms and even humans, while others have been linked to ecological perturbations through acute and chronic toxicity on aquatic flora and fauna [1]. Due to the incomplete TrOC degradation in wastewater treatment plants (WWTP), WWTP effluent is a major point source of TrOC pollution. The resistance of certain TrOCs to degradation by conventional wastewater treatment has prompted research on TrOC degradation by white-rot fungi [2].

White-rot fungi can efficiently degrade a wide range of organic compounds, including many that are resistant to bacterial degradation, via one or more extracellular enzymes including lignin peroxidases, manganese-dependent peroxidases and laccase. In addition to whole-cell preparations, removal of TrOCs has been investigated either by employing crude culture extract ('crude enzyme') or by purified enzymes $[2,3]$. Laccases are multi-copper containing enzymes that catalyze the oxidation of a wide range of phenolic substrates using oxygen as an electron acceptor [2]. The oxidation of a substrate typically involves the formation of a free radical after the transfer of a single electron to laccase. The oxidative efficiency of laccases depends on the redox potential difference between the reducing substrate and type 1 copper in laccase. Given the range of redox potentials that laccases from different fungi possess $(0.17-0.80 \mathrm{~V})$, non-phenolic substrates are often not amenable to direct oxidation by laccase $[4,5]$. To overcome this limitation, the use of 'redox mediators' has been proposed.

Mediators are small molecular weight compounds that are easily oxidized by laccase. The presence of mediators can expand the catalytic activity of laccase by increasing the redox potential of the enzyme solution. Mediators also act as an "electron shuttle," facilitating the oxidation of complex substrates that do not enter the active sites of the enzyme due to steric hindrances. Laccase oxidizes the mediators, generating highly reactive radicals, which then oxidize the target substrates [6, 7]. Three major mechanisms by which a mediator can oxidize a substrate have been reported in the literature, namely by hydrogen atom transfer (HAT), electron transfer and ionic mechanisms $[6,8]$. Commonly used mediators following the HAT pathway include small molecular weight phenolic compounds and compounds containing the structural group $=\mathrm{N}-\mathrm{OH}$. The oxidation of these mediators by laccase generates highly reactive phenoxyl $\left(\mathrm{C}_{6} \mathrm{H}_{5} \mathrm{O}^{*}\right)$ and aminoxyl $\left(=\mathrm{N}-\mathrm{O}^{*}\right)$ radicals, respectively owing to the enzymatic removal of an electron followed by release of a proton [9]. These radicals then extract a 
hydrogen atom from the substrate. With a few exceptions (e.g., [3, 10-12]), studies on the efficacy of these mediators to remove compounds resistant to conventional treatment has to date focused mostly on compounds other than TrOCs. Furthermore, a few studies have raised concern about the toxicity of the media following treatment by laccase-mediator systems [13-15]. However, there appears to be no study which has compared the performance of redox mediators in terms of enhancement of enzymatic degradation of a diverse set of TrOCs and the resulting toxicity of the treated solution. Such a study would help identify the type and dose of mediators that improve TrOC removal while minimizing toxicity of the treated media.

The aim of this study was to investigate the performance of an extracellular enzyme extract from Trametes versicolor (ATCC 7731) culture on the removal of a set of 30 TrOCs representing diverse chemical structures (e.g., phenolic and non-phenolic moieties and electron donating/ withdrawing functional groups). A special focus was given to the effect of augmenting enzymatic transformation with different dosages of two redox mediators, namely 1-hydroxybenzotriazole (HBT) and syringaldehyde (SA) on the removal performance and ultimate media toxicity. The study provides unique insights in light of the redox potential of the enzyme-mediator cocktail, the balance between the stability and reactivity of the radicals generated and their cytotoxic effects.

\section{Materials and methods}

\subsection{TrOC and mediators}

A set of 30 TrOCs, including 11 pharmaceuticals, six pesticides, five steroid hormones, three industrial chemicals, two phytoestrogens, and three UV filters was used in this study. Key properties of these compounds are listed in Supplementary Data Table S1. These TrOCs were selected in view of their widespread occurrence in wastewater and wastewater-impacted water bodies and represent different molecular properties such as phenolic vs. non-phenolic moieties and electron donating vs. withdrawing functional groups. All compounds were purchased from Sigma-Aldrich (Australia). A stock solution of the TrOCs was prepared at a concentration of $1 \mathrm{~g} / \mathrm{L}$ (each) in pure methanol, stored at $-18{ }^{\circ} \mathrm{C}$ and used within one month.

Two redox mediators, namely 1-hydroxybenzotriazole (HBT) and syringaldehyde (SA), were used in this study. HBT is a $=\mathrm{N}-\mathrm{OH}$ type mediator, while SA is a phenolic mediator (Supplementary Data Table S2). The oxidation of these mediators by laccase generates highly reactive aminoxyl $\left(=\mathrm{N}-\mathrm{O}^{*}\right)$ and 
phenoxyl $\left(\mathrm{C}_{6} \mathrm{H}_{5} \mathrm{O}^{*}\right)$ radicals, respectively, both of which follow the HAT pathway during substrate (TrOC) degradation [9]. These mediators were also purchased from Sigma-Aldrich (Australia). The mediators were prepared as a stock solution at a concentration of $50 \mathrm{mM}$ and stored at $4^{\circ} \mathrm{C}$.

\subsection{Extracellular enzyme extract}

Stock pure cultures of Trametes versicolor (ATCC 7731) were inoculated into Erlenmeyer flasks, each containing $50 \mathrm{~mL}$ of malt extract broth (Merck, Germany) at a concentration of $5 \mathrm{~g} / \mathrm{L}$. The $\mathrm{pH}$ of the medium was adjusted to 4.5 . The cultures were incubated on a rotary shaker at $70 \mathrm{rpm}$ and $28{ }^{\circ} \mathrm{C}$ for a week. The culture broth was harvested as 'crude enzyme' by decanting into sterilized bottles, which were stored at $4{ }^{\circ} \mathrm{C}$. Under the culture conditions, the $T$. versicolour strain used in this study secreted laccase as the main extracellular enzyme. Laccase activity was measured according to the method described in Section 2.4.2.

\subsection{Batch test description}

Crude enzyme solution ( $25 \mathrm{~mL}$ ) was added to $400 \mathrm{~mL}$ beakers. The initial enzymatic activity was $36 \pm$ $3 \mu \mathrm{M} / \mathrm{min}$ (See Section 2.4.2). The TrOC stock solution was added to the crude enzyme solution at a concentration of $100 \mu \mathrm{g} / \mathrm{L}$ (each). To investigate the effect of mediator addition, each of the mediators was added separately to obtain solutions with final mediator concentrations of $0.1,0.5$ and $1 \mathrm{mM}$. All experiments were conducted in triplicate. Controls comprised TrOCs in deionized (Milli-Q) water. The beakers were covered with aluminium foil and incubated on a rotary shaker at $70 \mathrm{rpm}$ and $25{ }^{\circ} \mathrm{C}$ for 24 h. At the end of the incubation period, the whole test medium was harvested. The samples were diluted to $500 \mathrm{~mL}$ with deionized (Milli-Q) water and filtered through $0.45 \mu \mathrm{m}$ glass fibre filters (Filtech, Australia). The $\mathrm{pH}$ of the sample was adjusted to 2 with $4 \mathrm{M} \mathrm{H}_{2} \mathrm{SO}_{4}$ before refrigerating until the solidphase extraction (SPE) and GC/MS analysis (Section 2.4.1) within 2 d. For toxicity assay, undiluted samples were kept at $4{ }^{\circ} \mathrm{C}$ until analyzed.

\subsection{Analytical methods}

\subsubsection{TrOC analysis}

TrOC concentration was measured by a previously reported analytical technique involving SPE, derivatisation and quantitative determination by a Shimadzu GC/MS (QP5000) system [16]. The GC/MS system was equipped with a Shimadzu AOC 20i autosampler and a Phenomenex Zebron ZB-5 (5\% diphenyl-95\% dimethyl polysiloxane) capillary column $\left(30 \mathrm{~m} \times 0.25 \mathrm{~mm} \mathrm{ID}, \mathrm{d}_{\mathrm{f}}=0.25 \mu \mathrm{m}\right)$. The 
quantitative limits of detection of this analytical method were compound specific and in the range from 1 to $20 \mathrm{ng} / \mathrm{L}$ (Supplementary Data Table S1). The aqueous phase TrOC removal efficiency was calculated by comparing initial and final concentrations.

\subsubsection{Enzymatic activity, redox potential and toxicity assay}

Under the experimental conditions of this study, the fungus predominantly secreted the extracellular enzyme laccase. Laccase activity was determined by monitoring the oxidation of 2, 6-dimethoxy phenol (DMP) in sodium citrate buffer ( $\mathrm{pH} 4.5$ ) over 2 min at room temperature. The reaction mixture contained $10 \mathrm{mM}$ of DMP, $100 \mathrm{mM}$ sodium citrate and the sample. The reaction was started by the addition of DMP to the mixture of the sample and buffer. The measurement was based on monitoring the change in absorbance at $468 \mathrm{~nm}$ by a spectrophotometer (Shimadzu, Japan). Laccase activity was then calculated from the molar extinction coefficient $\varepsilon=49.6 /(\mathrm{mM} . \mathrm{cm})$ and expressed in $\mu \mathrm{M}$ substrate/min [17]. The oxidation reduction potential (ORP) of the enzyme solution with and without mediator dosing was measured by an ORP probe (Orion Star, Thermo Fisher Scientific, Australia).

Bacterial toxicity was quantified for every sample from each batch in duplicate by measuring bioluminescence inhibition in Photobacterium leiognathi as described previously [18]. Toxicity was expressed as Relative Toxic Unit (rTU) calculated as $\mathrm{rTU}=1 / \mathrm{IC}_{20}$, with $\mathrm{IC}_{20}$ (concentration of the sample required to kill $20 \%$ of the bacteria) determined by linear regression of the toxicity response vs. relative sample enrichment within the linear range of the concentration-effect curve (up to $\mathrm{IC}_{40}$ ).

\section{Results and discussion}

\subsection{Degradation of TrOC by crude enzyme}

The oxidation of a substrate by laccase typically involves the formation of a free radical after the transfer of a single electron to laccase. It is well known that laccase efficiently promotes single electron oxidation of phenols i.e., compounds with hydroxyl groups linked to benzene ring [2]. For example, a major role of laccase in the course of lignin degradation is the oxidation of hydroxyl groups linked to the benzene ring to form phenoxyl radicals. Further rearrangement of phenoxyl radicals can occur with synchronous cleavage of alkyl-aryl bonds, oxidation of benzyl hydroxyls, cleavage of $\mathrm{C}_{\alpha}-\mathrm{C}_{\beta}$-bonds, or ring opening in a non-phenolic portion of the lignin structure [2]. Therefore, in this section TrOC degradation has been discussed based on the phenolic moiety of the compounds. 


\subsubsection{Degradation of phenolic compounds}

Of the 14 phenolic compounds tested in this study, a significant removal of nine compounds was observed. This included five steroid hormones (17 $\alpha$-ethinylestradiol, 17 $\beta$-estradiol, 17 $\beta$-estradiol-17acetate, estrone, and estriol (>95\%)), three industrial chemicals (bisphenol A, 4-tert-butylphenol, and 4-tert-octylphenol (>95\%)), and a personal care product (triclosan (65\%)) (Figure 1). The degradation rate of these TrOCs ranged from 60 to 104 ng/L.h (Supplementary Data Table S3). Degradation of only a few of these compounds, namely $17 \alpha$-ethinylestradiol, bisphenol A and 4-tert-butylphenol, has been studied before, with typically high removal being reported [2]. On the other hand, five phenolic compounds, namely formononetin, salicylic acid, oxybenzone, pentachlorophenol, and enterolactone were poorly degraded (less than 10\%; Figure 1). The enzymatic degradation of formononetin, salicylic acid and enterolactone has not been studied before; however, our observation regarding the removal of oxybenzone and pentachlorophenol is in line with the literature. For example, Garcia et al. [19] reported that oxybenzone was not directly oxidized by laccase derived from T. versicolor. Jeon et al. [20] also observed no removal of pentachlorophenol by laccase derived from Ganoderma lucidum, while Ullah et al. [21] observed complete removal of pentachlorophenol by laccase derived from Coriolus versicolor. The low removal of some phenolic compounds in this study may be because of i) inadequate oxidative efficiency of the laccase, which depends on the redox potential differences between the reducing substrate and the type 1 copper in laccase [13], and ii) the steric factors hindering the approach of the substrate to the active site of the enzyme and, consequently, inhibiting its oxidation $[4,22]$. For example, d'Acunzo et al. [23] reported that laccase from Polyporus pinsitus could not degrade 2,4,6-tri-tert-butylphenol due to steric hindrance. Similarly, according to Mizuno et al. [10] laccase from $T$. versicolor could not degrade parabens [10].

\section{[FIGURE 1]}

\subsubsection{Degradation of non-phenolic compounds}

As mentioned in the previous section, phenols are typical laccase substrates although laccase can directly oxidize some non-phenolic substrates if their electrochemical potential is sufficiently low [4]. In this study, the removal of 16 non-phenolic TrOCs was investigated (Figure 1). Except for the significant removal of diclofenac $(68 \%)$, low or negligible removal was observed for the remaining non-phenolic compounds. For a laccase with a given redox potential, differences in TrOC degradation can be explained based on the concept of impact of electron withdrawing functional groups (EWG) and 
electron donating functional groups (EDG) within the TrOC structure. TrOC which contain EWG (e.g., amide $\left(-\mathrm{CONR}_{2}\right)$, carbamate $\left(-\mathrm{CO}_{2} \mathrm{NR}_{2} \mathrm{H}\right)$, carboxylic $(-\mathrm{COOH})$, halogen $(-\mathrm{X})$, and nitro $\left.\left(-\mathrm{NO}_{2}\right)\right)$ have an electron deficiency and thus render the compounds less susceptible to oxidative catabolism whereas those with EDG (e.g., hydroxyl $(-\mathrm{OH})$ and amine $\left.\left(-\mathrm{NH}_{2}\right)\right)$ are prone to oxidative attack [24, 25]. In our study, the low/negligible removal of the chlorinated compounds such as clofibric acid, fenoprop, and atrazine (Figure 1) can be explained by the fact that the chloride group is a strong EWG. Treatment by laccase from $T$. versicolor was previously reported to inefficiently degrade clofibric acid [3]. Hai et al. reported negligible removal of atrazine by whole-cell culture of C. versicolour [26]. Poor removal of metronidazole, propoxur, and carbamazepine in our study can be attributed to the presence of a strong EWG (i.e., nitro, carbamate and amide, respectively) in their structures. The negligible removal of ametryn in our study is in line with the report of Mougin et al. [27] that the degradation of triazine pesticides can be initiated via N-dealkylation, but they are usually resistant to bacterial as well as fungal degradation. The high removal of diclofenac may be because of the aromatic amine in its structure, which possibly lowered its redox potential and made it amenable to oxidation by laccase. In this connection, it is noteworthy that except for triclosan, none of the phenolic TrOCs containing EWG was degraded by the crude enzyme extract (Figure 1).

Tran et al. [3] studied the degradation of several TrOCs. They reported that the degradation characteristics of the TrOCs by a commercial laccase and the crude enzyme obtained from the culture broth of the $T$. versicolor strain they used were similar. Although it was confirmed that the $T$. versicolor strain used in this study secreted laccase as the main extracellular enzyme (Section 2.2), a different strain and set of TrOCs than in the study of Tran et al. [3] were used in this study. Therefore, a direct comparison cannot be made between the observations made by Tran et al. [3] and the results reported in this study. Furthermore, crude enzyme extract can contain, in addition to laccase, a host of natural mediators and co-factors secreted by the fungus, which can enhance the performance of laccase [2]. Future research comparing the performance of crude and purified enzyme would provide valuable insight into the relative importance of laccase and the other biomolecules secreted by a specific strain in the degradation of the TrOCs under consideration.

\subsection{Effect of mediator addition on TrOC degradation}

\subsubsection{Overall improvement in TrOC degradation}

As noted in Section 3.1, of the 30 TrOCs tested, the crude enzyme extract could attain significant degradation of only ten compounds. We also added two mediators to the crude enzyme extract to test if any improvement in the remaining TrOC removal could be achieved. 
In a laccase-mediator system, the role of the enzyme is to oxidize the mediator, while the actual oxidation of the substrate takes place in a subsequent non-enzymatic step by the action of the oxidized mediator species. Therefore, the reaction mechanisms by which the radicals generated from the laccase-mediator system oxidize a substrate are important $[6,8]$. The oxidation of HBT and SA by laccase generates highly reactive aminoxyl $\left(=\mathrm{N}-\mathrm{O}^{*}\right)$ and phenoxyl $\left(\mathrm{C}_{6} \mathrm{H}_{5} \mathrm{O}^{*}\right)$ radicals, respectively. The aminoxyl radical oxidize the target substrate by the HAT mechanism $[8,13]$. Therefore, the enthalpic balance between the dissociated bond $(\mathrm{C}-\mathrm{H})$ in the target substrate and the forming bond $(\mathrm{NO}-\mathrm{H})$ in the mediator is the driving force of this mechanism [4,9]. It has been reported that phenoxyl radicals act analogously to aminoxyl radicals [4]. The HAT mechanism has been implicated in the oxidation of resistant compounds such as non-phenolic compounds [6, 8]. For instance, Bernini et al. [28] reported that the laccase-mediator system can effectively trigger the H-abstraction from benzylic carbons of non-phenolic compounds.

Figure 2 shows the effect of adding the mediators separately $(1 \mathrm{mM})$ to the crude enzyme extract (containing predominantly laccase) on the removal of the selected TrOCs. Mediator dosing extended the spectrum of efficiently degraded TrOCs to 13 phenolic and three non-phenolic compounds (i.e., atrazine, naproxen and diclofenac), with moderate improvements in removal of a few other nonphenolics. For example, the degradation rate of atrazine increased from negligible to over $50 \mathrm{ng} / \mathrm{L} . \mathrm{h}$. Similarly the degradation rate of naproxen improved from 20 to over $80 \mathrm{ng} / \mathrm{L} . \mathrm{h}$, while the degradation rate of diclofenac, which was already well removed without mediator addition, improved by only around 10 ng/L.h. (Supplementary Data Table S3).

The better performance of the mediator-amended crude enzyme extract may be explained by two factors attributable to the aminoxyl and phenoxyl radical species generated from HBT and SA by laccase, respectively: i) higher redox potential, and ii) reduction of steric hindrance. The oxidation of even some phenolic compounds by laccase may be hindered by solubility or steric issues. Low molecular weight mediators can interact with complex compounds that cannot directly access the enzyme active site. Moreover, compounds with high electrochemical potential can be oxidized by radical mediators (e.g., aminoxyl and phenoxyl) through the operation of H-abstraction mechanism. The laccase-mediator system can achieve better removal of compounds with high electrochemical potential as the oxidized mediator species have redox potentials higher than that of laccase only [5]. Figure 3 indeed demonstrates that in our study, the oxidation reduction potential of the crude enzyme extract increased significantly due to the addition of the mediators. The ORP of the crude enzyme 
extract with SA and HBT was 540 and $441 \mathrm{mV}$, respectively, which were significantly higher than that for the crude enzyme extract, SA solution and $\mathrm{HBT}$ solution $(207,249$ and $251 \mathrm{mV}$, respectively) (Figure 3). Our results are consistent with those of Weng et al. [11] who reported that the ORP of a range of mediators including SA was higher than that of laccase or the mediator separately, and thus higher degradation of sulfonamide antibiotics was achieved.

[FIGURE 2]

\section{[FIGURE 3]}

The factors and mechanisms discussed in this section may explain the significantly improved degradation of the phenolic TrOCs (i.e., formononetin, salicylic acid, oxybenzone, pentachlorophenol and enterolactone) and the non-phenolic TrOCs (i.e., primidone, atrazine, amitriptyline, octocrylene, naproxen, and diclofenac) in our study in the presence of the mediators (Figure 2). Aminoxyl radicals generated from oxidation of HBT by laccase from the fungus $T$. villosa were previously shown to carry out H-abstraction from certain amide substrates [29]. However, the lack of improvement in the removal of the amide compound carbamazepine observed in this study is probably due to the difference in redox potential of laccase from different Trametes species as well as the specific structure of the compounds.

\subsubsection{Comparison between the mediators}

In this study, HBT achieved better removal than SA for four phenolic compounds, namely salicylic acid, oxybenzone, pentachlorophenol and enterolactone, and three non-phenolic compounds, namely primidone, atrazine, and naproxen (Figure 2). By contrast, SA led to better removal of the phenolic compound formononetin and the non-phenolic compound octocrylene, while similar removal of the non-phenolic compound amitriptyline was achieved by the mediators. No relevant data could be retrieved from the literature for a direct comparison with our data. However, in general, there appears to be no clear consensus on the comparative performance of SA and HBT. For example, Khlifi-Slama et al. [30] reported that a laccase-HBT system achieved the best decolorization of a textile industry effluent among the nine mediators tested including SA. On the other hand, Camarero et al. [31]

reported better degradation by SA than HBT for a range of phenolic and non-phenolic dyes possessing strong EWG.

The performance of the laccase-mediator systems depends on the electrochemical potential of the radical generated, redox reversibility of the reaction of the radical with the substrate, as well as on the 
balance between the stability and reactivity of the mediator radical [31]. As noted in Section 3.2.1, both SA and HBT act via the HAT mechanism. In addition, in this study, the ORP values of the crude enzyme solution amended with the mediators separately were not significantly different (Figure 3). Therefore, the difference in the performance of the two mediators may be attributed to the overall stability of the radicals generated. Both radicals (phenoxyl and aminoxyl) have a very short half-life due to their poor thermostability. For example, the half-life of the aminoxyl radical generated due to oxidation of HBT by laccase is $120 \mathrm{~s}$ [32]. Phenoxyl radicals (from SA) have often been reported to be more active but they are highly unstable and turn into quinone which is much less active [13]. Although the aminoxyl radicals also convert rapidly to benzotriazole and other inactive compounds, their stability and reactivity have been reported to be better balanced than that of phenoxyl radicals [13]. In our study, this is further evidenced by the fact that at the end of the incubation period, the ORP of the SAamended solution demonstrated a $45 \%$ reduction from the initial value as compared to a $25 \%$ reduction in case of the HBT-amended solution (Figure 3). This may explain the better performance of HBT observed in our study.

\subsubsection{Effect of mediator concentration on TrOC removal and enzymatic stability}

As mentioned in section 3.2.2, the abundance and stability of the oxidized intermediates from the mediators affect TrOC degradation. Mediator concentration can influence both the abundance and stability of oxidized intermediates. Here, the effect of three different concentrations $(0.1,0.5$, and 1 $\mathrm{mM}$ ) of the mediators (SA and HBT) on TrOC removal is discussed focusing on the five phenolic and five non-phenolic compounds for which the mediators produced significant improvement in removal (Figure 2 and 4). The complete data set is presented in Supplementary Data Figure S4 and S5.

In this study, TrOC degradation improved by up to 60 and $95 \%$ using SA and HBT, respectively (Figure 4). The ORP of the crude enzyme extract was not significantly different between different dosages of SA and HBT (Figure 5). In accordance with that, approximately similar removal efficiencies were achieved for all three tested concentrations of SA (Figure 4). On the other hand, the removals on addition of $\mathrm{HBT}$ at 0.5 and $1 \mathrm{mM}$ were similar but significantly better than that at $0.1 \mathrm{mM}$ (Figure 4). Our results are in line with the general trend observed in the literature that pollutant removal profile may reach a plateau beyond a certain mediator concentration, and that such threshold concentrations depend on the source of laccase, the target compound and the mediator used. For example, Mizuno et al. [10] found a gradual increase in iso-butylparaben and n-butylparaben removal due to addition of 
HBT to laccase (from T. versicolor) over a concentration range of 0.2 to $2 \mathrm{mM}$, beyond which no further improvement was observed. By contrast, Lloret et al. [15] obtained diclofenac removal in a range from 40 to $80 \%$ for the SA concentrations ranging from 0.1 to $0.5 \mathrm{mM}$, while complete removal was achieved at $1 \mathrm{mM}$.

\section{[FIGURE 4]}

The free radicals generated from laccase-mediator systems that can improve pollutant degradation may inactivate laccase by oxidizing the aromatic amino acid residues on the proteinaceous enzyme surface [33]. However, the range of mediator concentrations beyond which fast and significant laccase inactivation occurs tends to vary depending on the source of laccase and the type of the mediator. For example, in a study by Khlifi-Slama et al. [33], a gradual increase in the degree of inactivation of laccase from T. trogii was observed for HBT concentrations from 0.1 to $10 \mathrm{mM}$. On the other hand, Kurniawati and Nicell [34] observed only a slight inactivation $(<5 \%)$ of laccase from T. versicolor when a range of different mediators was used at concentrations up to $0.5 \mathrm{mM}$. In this study, when no mediators were added, the loss of laccase activity was $8 \%$, possibly due to the rotational shaking (agitation) during incubation [17]. In contrast, depending on the mediator concentration (0.1 to $1 \mathrm{mM})$, the loss of laccase activity ranged from 14 to 39\% (Figure 5). This gradual inactivation may be a contributing factor to the lack of increase in TrOC degradation beyond a dosage of $0.1 \mathrm{mM}$ for SA and $0.5 \mathrm{mM}$ for HBT.

\section{[FIGURE 5]}

Cost is an important consideration for practical implementation of a treatment process. While this study provides unique insights on the effect of augmenting enzymatic transformation with different dosage of HBT and SA on the TrOC removal performance, scale up of the system is a critical prerequisite to a meaningful economical assessment. Malt extract broth was used to obtain crude enzyme extract in this study. However, practical implementation would require selection of a more inexpensive medium such as agricultural residues. Given the potential of use of such renewable inexpensive growth medium, it appears that mediator cost will comprise a major fraction of the material cost. While the importance of feasibility assessment of the process cannot be overlooked, further detailed coverage of the cost analysis is beyond the scope of this study. 


\subsection{Toxicity of the treated media}

Because investigations were carried out with a mixture of $30 \mathrm{TrOCs}$, it would be virtually impossible to detect let alone quantify each transformation product. We have, instead, studied the toxicity of the treated media (Section 3.3), which provides a measure of the overall toxicity of all compounds, including degradation products. A few recent studies have reported increased toxicity of white-rot fungi-treated media despite efficient degradation of the target pollutant $[12,15,35]$. However, there appears to be no specific literature regarding comparison of toxicity following laccase-HBT or laccaseSA catalyzed treatment of TrOC. Therefore, in this study, the toxicity of the media after enzymatic treatment with different dosage of the mediators was tested.

In comparison to the toxicity of the control (TrOC solution in Milli-Q water), a slight decrease in the toxicity after treatment with the crude enzyme extract (no mediators) was observed (Figure 6). However, a mediator concentration-specific toxicity of the treated media was observed in case of the laccase-mediator systems. The toxicity of the treated media may be due to the aminoxyl or phenoxyl radicals formed in the laccase-mediator system and/or the metabolites produced during the TrOC degradation. However, the following two observations indicate that the toxicity may have been due to the radicals formed in presence of both laccase and mediators, and not specifically due to the TrOC degradation products or the mediator itself: (i) TrOC degradation by laccase (in the absence of mediators) did not increase toxicity (Figure 6), indicating non-toxic by products, and (ii) incubation with mediator solution (in the absence of laccase) revealed no toxicity. Fillat et al. [35] also observed a negligible contribution of non-oxidized mediators to effluent toxicity. Kim and Nicell [14] suggested that radicals formed due to oxidation of mediators can interact with vitally important biomolecules and result in cytotoxic effects.

\section{[FIGURE 6]}

The toxicity of the test media treated with laccase-HBT was comparable at HBT doses of 0.1 and 0.5 $\mathrm{mM}$, but increased at the higher HBT concentration of $1 \mathrm{mM}(88.6 \pm 3.9 \mathrm{rTU}$ vs. $6.2 \pm 1.1 \mathrm{rTU}$ of control). The toxicity of the laccase-HBT solution was however much lower than the laccase-SA solution $(8240 \pm 1336,14202 \pm 5894$, and $15250 \pm 4359$ rTU for the SA doses of 0.1, 0.5 and $1 \mathrm{mM}$, respectively). The higher toxicity of SA is consistent with a study by Fillat et al. [35], who reported that under the same mediator concentration, the toxicity of laccase-SA treated flax pulp effluent was 10 
to 20 -fold higher than of laccase-HBT treated effluent, but did not offer any explanation behind this observation. It is possible that radicals formed due to oxidation of SA interact with the vitally important biomolecules in a different manner. For example, Cortez et al. [36] reported inhibition of growth of Candida guilliermondii and its xylitol production due to SA, and noted that unlike some other phenolic compounds the microbial activity inhibition mechanism of SA was not directly related to damaging the integrity of the cell membrane but comprised respiration inhibition. Lack of relevant information in the literature restricts offering further insight to the difference between the behavior of SA and HBT.

Whilst the observations made in this study are generally consistent with the available information, elucidation of the critical influence of the type and the dose of the mediators is a novel outcome of this study. The toxicity of the treated media due to the addition of mediator requires further research: screening of non-toxic mediator and optimizing the mediator concentration are potential approaches to addressing this issue. Furthermore, investigations specifically aimed at identification of metabolites are needed to clarify the relative contribution of TrOC-metabolites and mediator to treated media toxicity. However, these aspects are beyond the scope of this study.

\section{Conclusion}

This is the first study to reveal the dosage-specific comparative enhancement of enzymatic degradation of a set of 30 trace organic contaminants by two redox-mediators, namely 1-hydroxybenzotriazole (HBT) and syringaldehyde (SA). Crude enzyme extract (predominantly laccase) from T. versicolor efficiently (70-95\%) degraded nine phenolic and one non-phenolic TrOCs. HBT and SA, which produce aminoxyl and phenoxyl radicals, respectively, achieved significant removal of additional five phenolic and two non-phenolic TrOCs, with moderate removal of a few other non-phenolics. The improved removal may be attributed to the increase in redox potential of the enzyme solution following mediator addition. However, despite the similar redox potentials of the enzyme-mediator cocktail for HBT and SA, SA achieved less efficient degradation and did not exhibit significant improvement in degradation at concentrations higher than $0.1 \mathrm{mM}$, indicating the imbalance between the stability and reactivity of the radicals generated. Addition of SA at all concentrations $(0.1-1 \mathrm{mM})$ also resulted in a $>1000$-fold increase in bacterial cytotoxicity. In contrast, only the higher HBT dose (1 mM) produced measurable toxicity, with no detectable increase in toxicity at lower doses (0.1-0.5 mM).. Overall, addition of HBT at a concentration of $0.5 \mathrm{mM}$ achieved the best removal without raising any increase in toxicity of the treated media. 


\section{Acknowledgement}

A PhD scholarship to Luong N. Nguyen from the University of Wollongong is greatly appreciated. We thank Kalinda Watson for assistance with the toxicity assay.

\section{References}

[1] Alexander JT, Hai FI, Al-aboud TM. Chemical coagulation-based processes for trace organic contaminant removal: Current state and future potential. J. Environ. Manage. 2012; 111: 195-207.

[2] Yang S, Hai FI, Nghiem LD, Price WE, Roddick F, Moreira MT, Magram SF. Understanding the factors controlling the removal of trace organic contaminants by white-rot fungi and their lignin modifying enzymes: A critical review. Bioresource Technol 2013; 141: 97-108.

[3] Tran NH, Urase T, Kusakabe O. Biodegradation characteristics of pharmaceutical substances by whole fungal culture Trametes versicolor and its laccase. J Water Environ Technol 2010; 8: 125-40.

[4] Cañas AI, Camarero S. Laccases and their natural mediators: Biotechnological tools for sustainable ecofriendly processes. Biotechnol. Adv 2010; 28: 694-705.

[5] Klonowska A, Gaudin C, Fournel A, Asso M, Le Petit J, Giorgi M, Tron T. Characterization of a low redox potential laccase from the basidiomycete C30. Eur. J. Biochem. 2002; 269: 6119-25.

[6] Astolfi P, Brandi P, Galli C, Gentili P, Gerini MF, Greci L, Lanzalunga O. New mediators for the enzyme laccase: mechanistic features and selectivity in the oxidation of non-phenolic substrates. New J. Chem. 2005; 29: 1308-17.

[7] Shiraishi T, Sannami Y, Kamitakahara H, Takano T. Comparison of a series of laccase mediators in the electro-oxidation reactions of non-phenolic lignin model compounds. Electrochim. Acta 2013; 106: 440-6.

[8] Fabbrini M, Galli C, Gentili P. Comparing the catalytic efficiency of some mediators of laccase. J.Mol. Catal. B. Enzym. 2002; 16: 231-40.

[9] d'Acunzo F, Baiocco P, Galli C. A study of the oxidation of ethers with the enzyme laccase under mediation by two N-OH-type compounds. New J. Chem. 2003; 27: 329-32.

[10] Mizuno H, Hirai H, Kawai S, Nishida T. Removal of estrogenic activity of iso-butylparaben and nbutylparaben by laccase in the presence of 1-hydroxybenzotriazole. Biodegradation 2009; 20: 533-9.

[11] Weng S-S, Ku K-L, Lai H-T. The implication of mediators for enhancement of laccase oxidation of sulfonamide antibiotics. Bioresource Technol 2012; 113: 259-64.

[12] Nguyen LN, Hai FI, Yang S, Kang J, Leusch FDL, Roddick F, Price WE, Nghiem LD. Removal of pharmaceuticals, steroid hormones, phytoestrogens, UV-filters, industrial chemicals and pesticides by Trametes versicolor:Role of biosorption and biodegradation. Int Biodeterior Biodegradation 2014; 88: 169-75. 
[13] Xu F, Kulys JJ, Duke K, Li K, Krikstopaitis K, Deussen H-JW, Abbate E, Galinyte V, Schneider P. Redox chemistry in laccase-catalyzed oxidation of N-hydroxy compounds. Appl. Environ. Microbiol. 2000; 66: 2052-6. [14] Kim Y-J, Nicell JA. Laccase-catalysed oxidation of aqueous triclosan. J Chem Technol Biotechnol 2006; 81: 1344-52.

[15] Lloret L, Eibes G, Lú-Chau TA, Moreira MT, Feijoo G, Lema JM. Laccase-catalyzed degradation of antiinflammatories and estrogens. Biochem. Eng. J. 2010; 51: 124-31.

[16] Hai FI, Tessmer K, Nguyen LN, Kang J, Price WE, Nghiem LD. Removal of micropollutants by membrane bioreactor under temperature variation. J. Membr. Sci. 2011; 383: 144-51.

[17] Hai FI, Yamamoto K, Nakajima F, Fukushi K. Application of a GAC-coated hollow fiber module to couple enzymatic degradation of dye on membrane to whole cell biodegradation within a membrane bioreactor. J. Membr. Sci. 2012; 389: 67-75.

[18] Nguyen LN, Hai FI, Yang S, Kang J, Leusch FDL, Roddick F, Price WE, Nghiem LD. Removal of trace organic contaminants by an MBR comprising a mixed culture of bacteria and white-rot fungi. Bioresource Technol 2013; 148: 234-41.

[19] Garcia HA, Hoffman CM, Kinney KA, Lawler DF. Laccase-catalyzed oxidation of oxybenzone in municipal wastewater primary effluent. Water Res. 2011; 45: 1921-32.

[20] Jeon J-R, Murugesan K, Kim Y-M, Kim E-J, Chang Y-S. Synergistic effect of laccase mediators on pentachlorophenol removal by Ganoderma lucidum laccase. Appl. Microbiol. Biotechnol. 2008; 81: 783-90.

[21] Ullah MA, Bedford CT, Evans CS. Reactions of pentachlorophenol with laccase from Coriolus versicolor. Appl. Microbiol. Biotechnol. 2000; 53: 230-4.

[22] d'Acunzo F, Galli C, Gentili P, Sergi F. Mechanistic and steric issues in the oxidation of phenolic and nonphenolic compounds by laccase or laccase-mediator systems. The case of bifunctional substrates. New J. Chem. 2006; 30: 583-91.

[23] d'Acunzo F, Galli C. First evidence of catalytic mediation by phenolic compounds in the laccase-induced oxidation of lignin models. Eur. J. Biochem. 2003; 270: 3634-40.

[24] Tadkaew N, Hai FI, McDonald JA, Khan SJ, Nghiem LD. Removal of trace organics by MBR treatment: The role of molecular properties. Water Res 2011; 45: 2439-51.

[25] Hai FI, Tadkaew N, McDonald JA, Khan SJ, Nghiem LD. Is halogen content the most important factor in the removal of halogenated trace organics by MBR treatment? Bioresource Technol 2011; 102: 6299-303.

[26] Hai FI, Modin O, Yamamoto K, Fukushi K, Nakajima F, Nghiem LD. Pesticide removal by a mixed culture of bacteria and white-rot fungi. J. Taiwan Inst. Chem. Eng. $\quad$ 2012; 43: 459-62.

[27] Mougin C, Laugero C, Asther M, Chaplain V. Biotransformation of s-triazine herbicides and related degradation products in liquid cultures by the white rot fungus Phanerochaete chrysosporium. Pestic Sci 1997; 49: 169-77. 
[28] Bernini R, Crisante F, Gentili P, Morana F, Pierini M, Piras M. Chemoselective C-4 aerobic oxidation of catechin derivatives catalyzed by the Trametes villosa laccase/1-hydroxybenzotriazole system: Synthetic and mechanistic aspects. J Org Chem 2011; 76: 820-32.

[29] Coniglio A, Galli C, Gentili P, Vadalà R. Oxidation of amides by laccase-generated aminoxyl radicals. J.Mol. Catal. B. Enzym. 2008; 50: 40-9.

[30] Khlifi R, Belbahri L, Woodward S, Ellouz M, Dhouib A, Sayadi S, Mechichi T. Decolourization and detoxification of textile industry wastewater by the laccase-mediator system. J. Hazard. Mater. 2010; 175: 802-8. [31] Camarero S, Ibarra D, Martínez MJ, Martínez ÁT. Lignin-derived compounds as efficient laccase mediators for decolorization of different types of recalcitrant dyes. Appl. Environ. Microbiol. 2005; 71: 1775-84.

[32] Coniglio A, Galli C, Gentili P, Vadala R. Hydrogen atom abstraction from C-H bonds of benzylamides by the aminoxyl radical BTNO: A kinetic study. Org. Biomol. Chem. 2009; 7: 155-60.

[33] Khlifi-Slama R, Mechichi T, Sayadi S, Dhouib A. Effect of natural mediators on the stability of Trametes trogii laccase during the decolourization of textile wastewaters. J. Microbiol 2012; 50: 226-34.

[34] Kurniawati S, Nicell JA. Efficacy of mediators for enhancing the laccase-catalyzed oxidation of aqueous phenol. Enzyme Microb. Technol. 2007; 41: 353-61.

[35] Fillat A, Colom JF, Vidal T. A new approach to the biobleaching of flax pulp with laccase using natural mediators. Bioresource Technol 2010; 101: 4104-10.

[36] Cortez DV, Roberto IC. Individual and interaction effects of vanillin and syringaldehyde on the xylitol formation by Candida guilliermondii. Bioresource Technol 2010; 101: 1858-65. 


\section{LIST OF FIGURE}

Figure 1: Removal of 30 TrOC by crude enzyme extract from T. versicolor (ATCC 7731). The error bars represent the standard deviation of three replicates.

Figure 2 Removal of 30 TrOC by crude enzyme extract from T. versicolor (ATCC 7731) in the presence of two mediators (SA and HBT) at a concentration of $1 \mathrm{mM}$. The error bars represent the standard deviation of three replicates.

Figure 3: Oxidation reduction potential of enzyme, mediator and mediator-amended enzyme solutions at a mediator concentration of $1 \mathrm{mM}$. The error bars represent the standard deviation of three replicates.

Figure 4: Effect of mediator concentrations on phenolic and non-phenolic TrOC removal improvement. The error bars represent the standard deviation of three replicates.

Figure 5: Impact of mediator concentration on the oxidation reduction potential and the enzyme inactivation. The error bars represent the standard deviation of three replicates. Enzyme inactivation $(\%)=($ Initial - Final enzymatic activity) / Initial enzymatic activity. Enzyme inactivation for the enzyme solution without mediators was $8 \%$.

Figure 6: Comparison of toxicity following enzymatic treatment with and without the mediators. TrOC solution in Milli-Q water served as the control. The error bars represent the standard deviation of two replicates. 


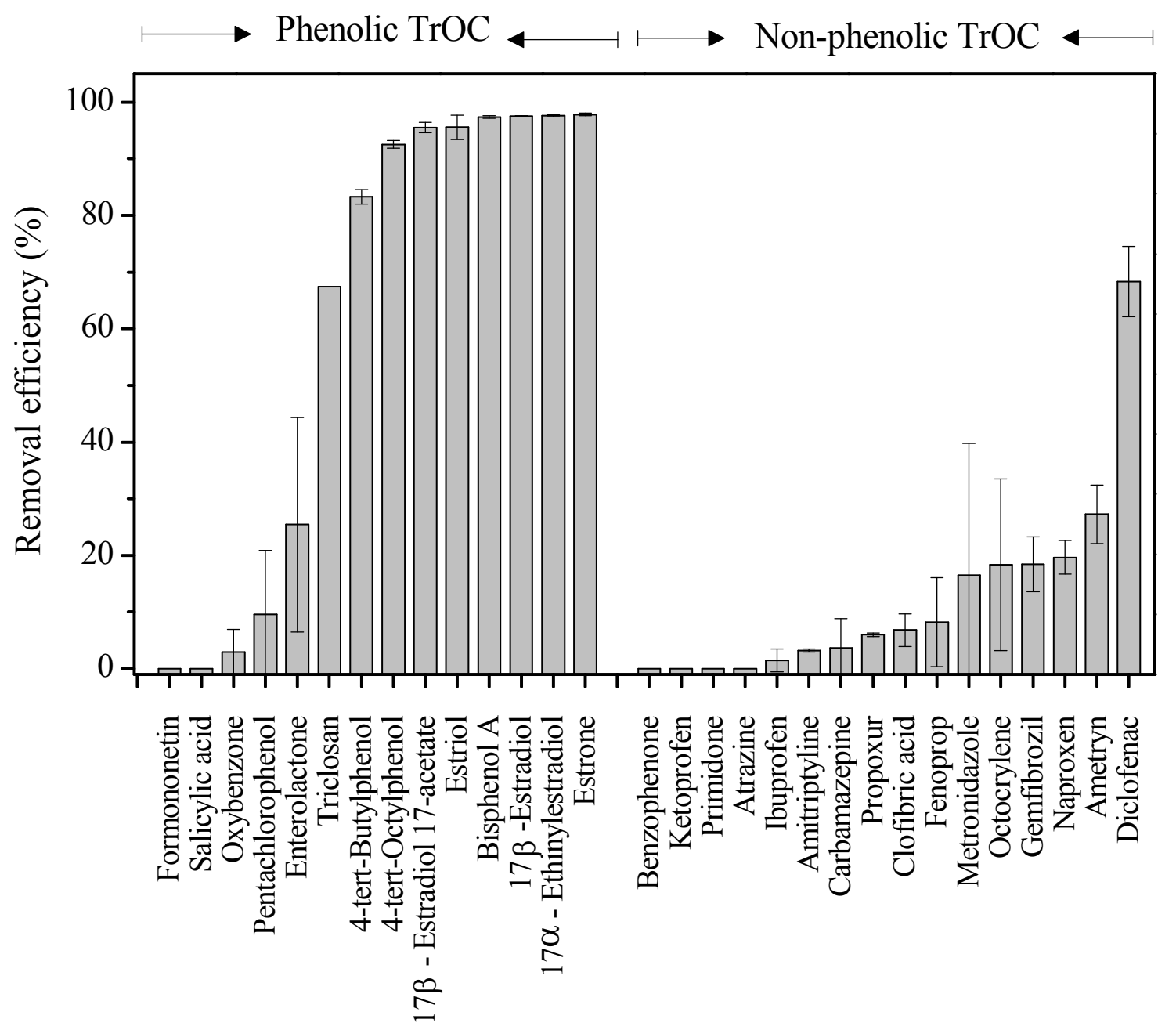

Figure 1 


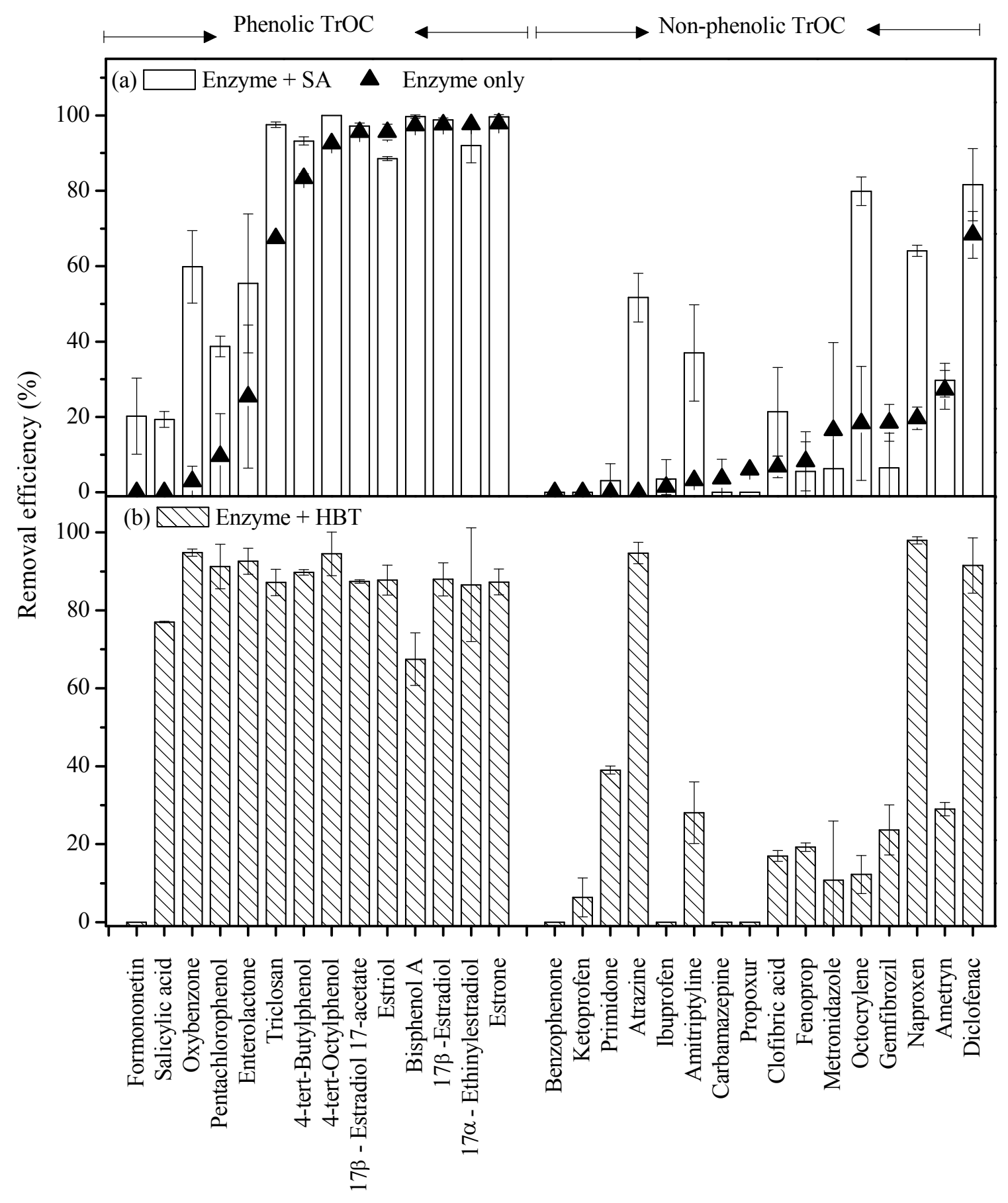

Figure 2 


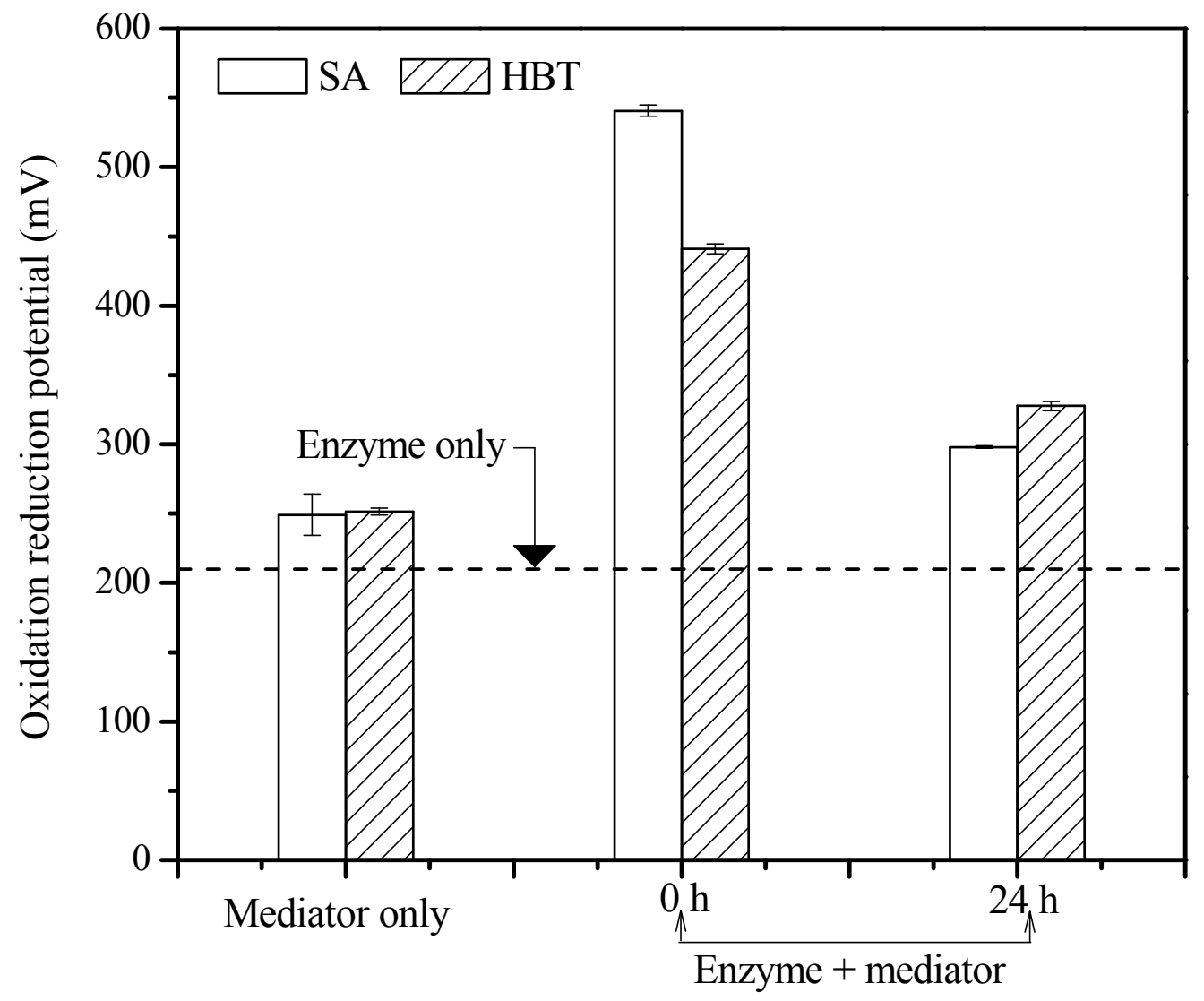

Figure 3 

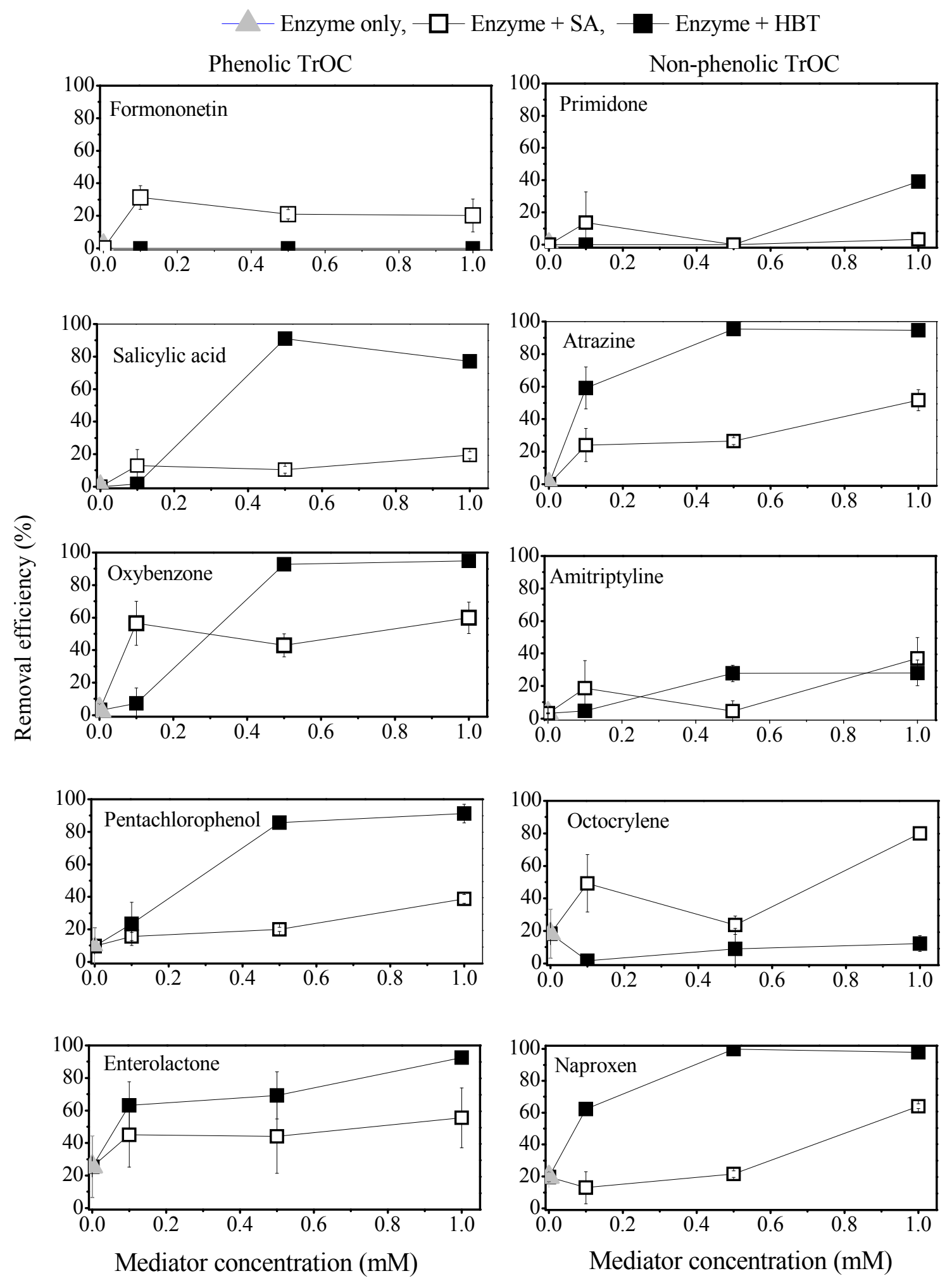

Figure 4 


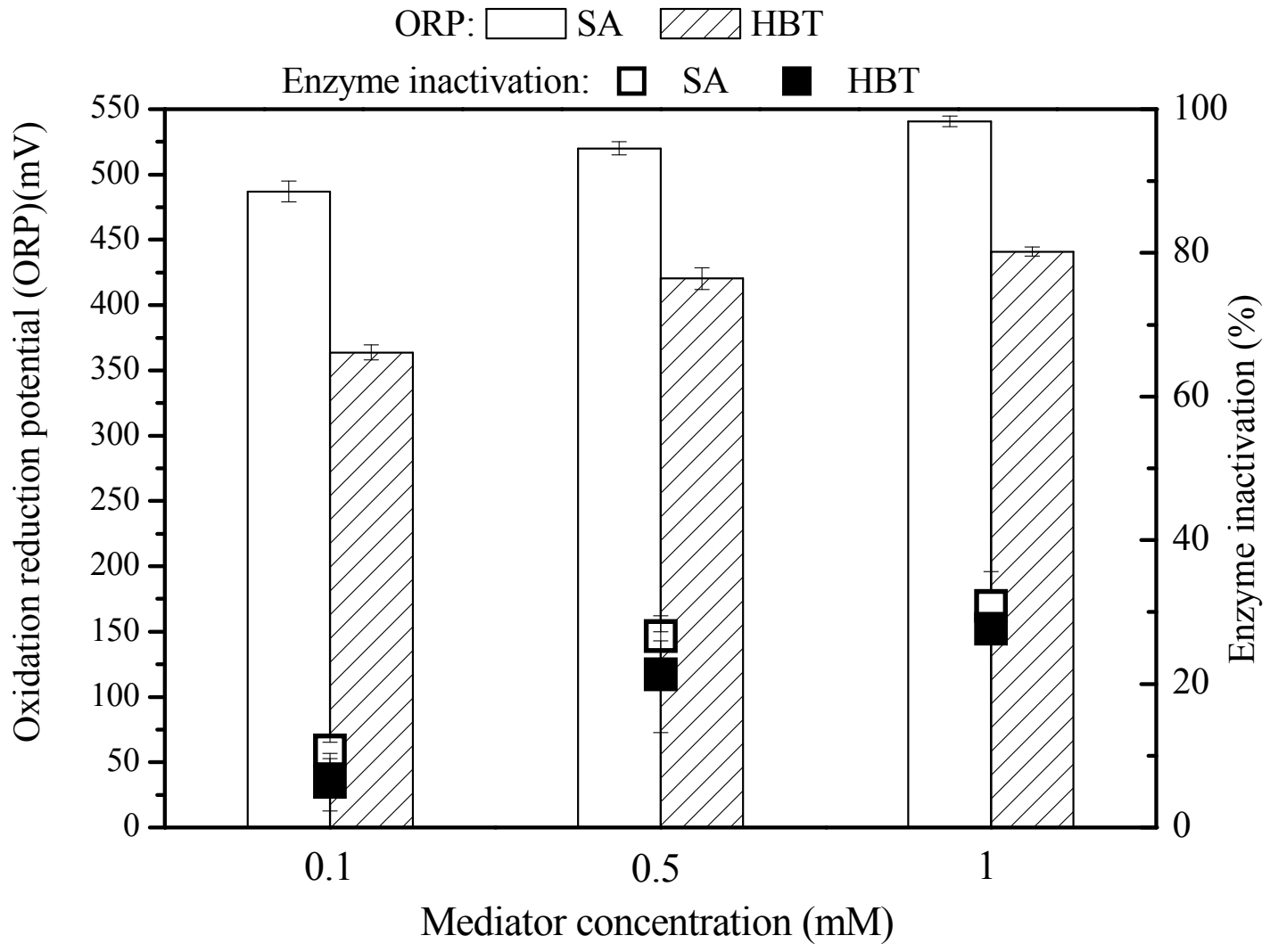

Figure 5 


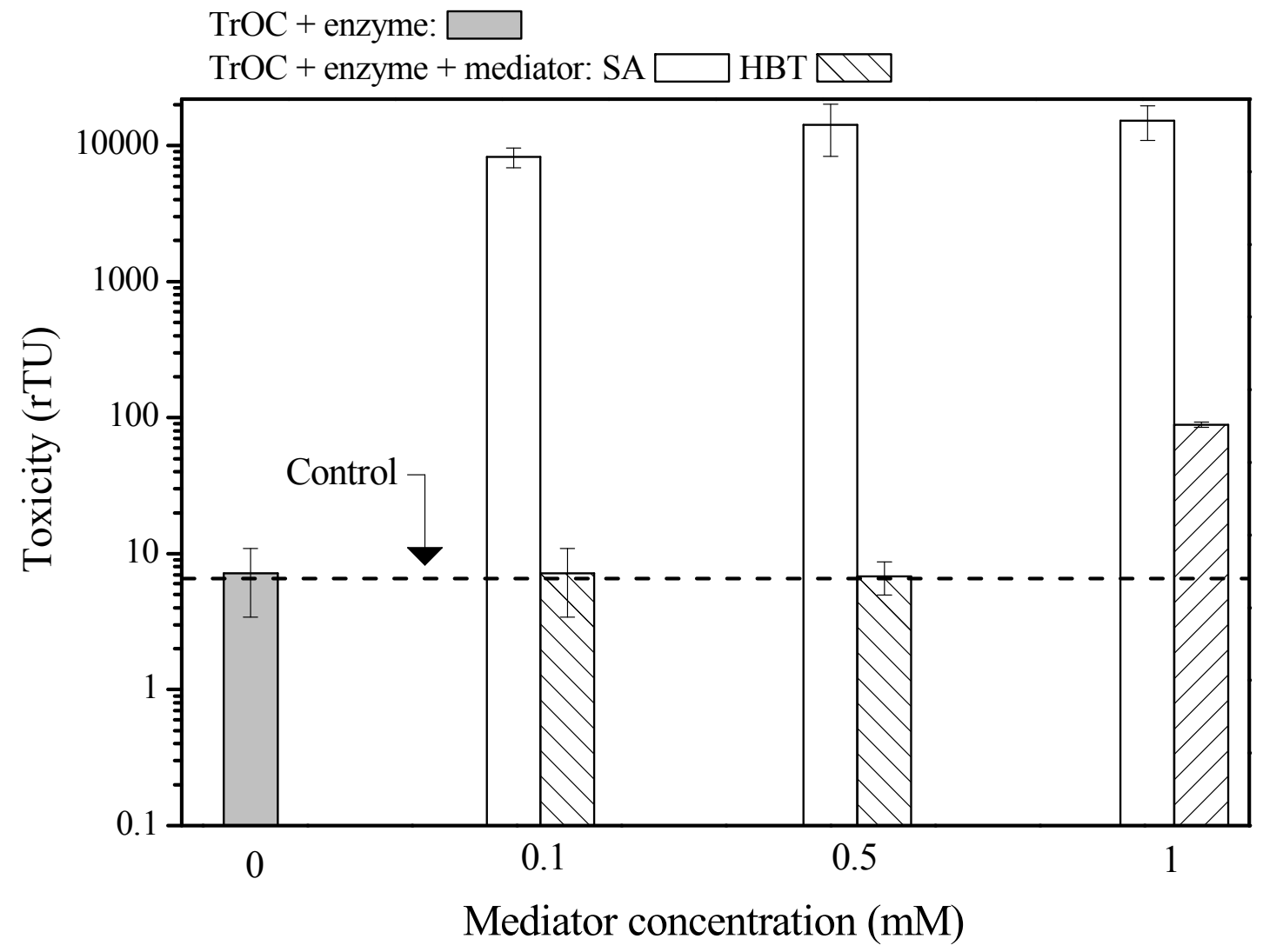

Figure 6 
Enhancement of trace organic contaminant degradation by crude enzyme extract from Trametes versicolor culture: Effect of mediator type and concentration

\section{Journal of the Taiwan Institute of Chemical Engineers}

Luong N. Nguyen ${ }^{\text {a }}$, Faisal I. Hai ${ }^{a^{*}}$, Jinguo Kang ${ }^{b}$, Frederic D. L. Leusch ${ }^{c}$, Felicity Roddick ${ }^{d}$, Saleh F. Magram ${ }^{\mathrm{e}}$, William E. Price ${ }^{\mathrm{b}}$, and Long D. Nghiem ${ }^{\mathrm{a}}$

${ }^{a}$ Strategic Water Infrastructure Laboratory, School of Civil, Mining and Environmental Engineering, University of Wollongong, Wollongong, NSW 2522, Australia

${ }^{\mathrm{b}}$ Strategic Water Infrastructure Laboratory, School of Chemistry, University of Wollongong, Wollongong, NSW 2522, Australia

${ }^{\mathrm{c}}$ Smart Water Research Centre, School of Environment, Griffith University, Southport, QLD 4222, Australia

${ }^{\mathrm{d}}$ School of Civil, Environmental and Chemical Engineering, RMIT University, Melbourne, Victoria 3001, Australia

${ }^{\mathrm{e}}$ Department of Civil Engineering, King Abdul Aziz University, Jeddah 21589, Saudi Arabia

* Corresponding author: Faisal I. Hai, Email: faisal@uow.edu.au; Ph: +61 242213054 
Table S1: Physicochemical properties of the selected trace organic contaminants (TrOC).

\begin{tabular}{|c|c|c|c|c|c|c|}
\hline Category & $\begin{array}{c}\text { Compound } \\
\text { (CAS number) }\end{array}$ & $\begin{array}{l}\text { Molecular } \\
\text { weight } \\
(\mathrm{g} / \mathrm{mol})\end{array}$ & $\begin{array}{l}\log \mathrm{D} \\
(\mathrm{pH} 5)^{\mathrm{a}}\end{array}$ & $\begin{array}{l}\text { Dissocia } \\
\text { tion } \\
\text { constant } \\
(\mathrm{pKa})^{\mathrm{a}}\end{array}$ & $\begin{array}{l}\text { Limit of } \\
\text { detection } \\
(\mathrm{ng} / \mathrm{L})^{\mathrm{b}}\end{array}$ & Chemical structure \\
\hline \multirow{8}{*}{ 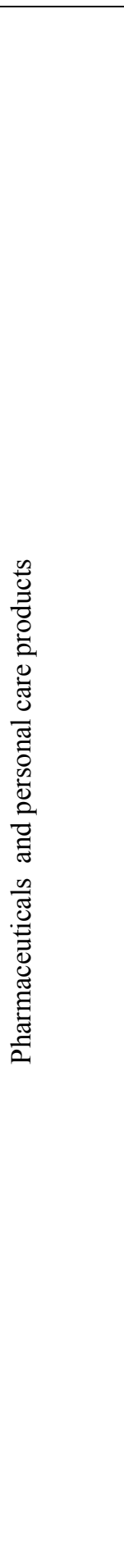 } & $\begin{array}{l}\text { Ibuprofen } \\
\left(\mathrm{C}_{13} \mathrm{H}_{18} \mathrm{O}_{2}\right) \\
(5687-27-1)\end{array}$ & 206.28 & 2.81 & $\begin{array}{c}4.41 \pm \\
0.10\end{array}$ & 20 & \\
\hline & $\begin{array}{c}\text { Naproxen } \\
\left(\mathrm{C}_{14} \mathrm{H}_{14} \mathrm{O}_{3}\right) \\
(22204-53-1)\end{array}$ & 230.26 & 2.49 & $\begin{array}{c}4.84 \pm \\
0.30\end{array}$ & 1 & \\
\hline & $\begin{array}{l}\text { Ketoprofen } \\
\left(\mathrm{C}_{16} \mathrm{H}_{14} \mathrm{O}_{3}\right) \\
(22071-15-4)\end{array}$ & 254.28 & 2.07 & $\begin{array}{c}4.23 \pm \\
0.10\end{array}$ & 20 & \\
\hline & $\begin{array}{c}\text { Diclofenac } \\
\left(\mathrm{C}_{14} \mathrm{H}_{11} \mathrm{Cl}_{2} \mathrm{NO}_{2}\right) \\
(15307-86-5)\end{array}$ & 296.15 & 3.66 & $\begin{array}{c}4.18 \pm \\
0.10 \\
-2.26 \pm \\
0.50\end{array}$ & 5 & \\
\hline & $\begin{array}{c}\text { Primidone } \\
\left(\mathrm{C}_{12} \mathrm{H}_{14} \mathrm{~N}_{2} \mathrm{O}_{2}\right) \\
(125-33-7)\end{array}$ & 218.25 & 0.83 & $\begin{array}{c}12.26 \pm \\
0.40 \\
\\
-1.07 \pm \\
0.40\end{array}$ & 10 & \\
\hline & $\begin{array}{l}\text { Carbamazepine } \\
\left.\qquad \mathrm{C}_{15} \mathrm{H}_{12} \mathrm{~N}_{2} \mathrm{O}\right) \\
(298-46-4)\end{array}$ & 236.27 & 1.89 & $\begin{array}{c}13.94 \pm \\
0.20 \\
\\
-0.49 \pm \\
0.20\end{array}$ & 10 & \\
\hline & $\begin{array}{c}\text { Salicylic acid } \\
\left(\mathrm{C}_{7} \mathrm{H}_{6} \mathrm{O}_{3}\right) \\
(69-72-7)\end{array}$ & 138.12 & -0.65 & $\begin{array}{c}3.01 \pm \\
0.10\end{array}$ & 1 & \\
\hline & $\begin{array}{c}\text { Metronidazole } \\
\left(\mathrm{C}_{6} \mathrm{H}_{9} \mathrm{~N}_{3} \mathrm{O}_{3}\right) \\
(443-48-1)\end{array}$ & 171.15 & -0.14 & $\begin{array}{c}14.44 \pm \\
0.10 \\
\\
2.58 \pm \\
0.34\end{array}$ & 20 & \\
\hline
\end{tabular}




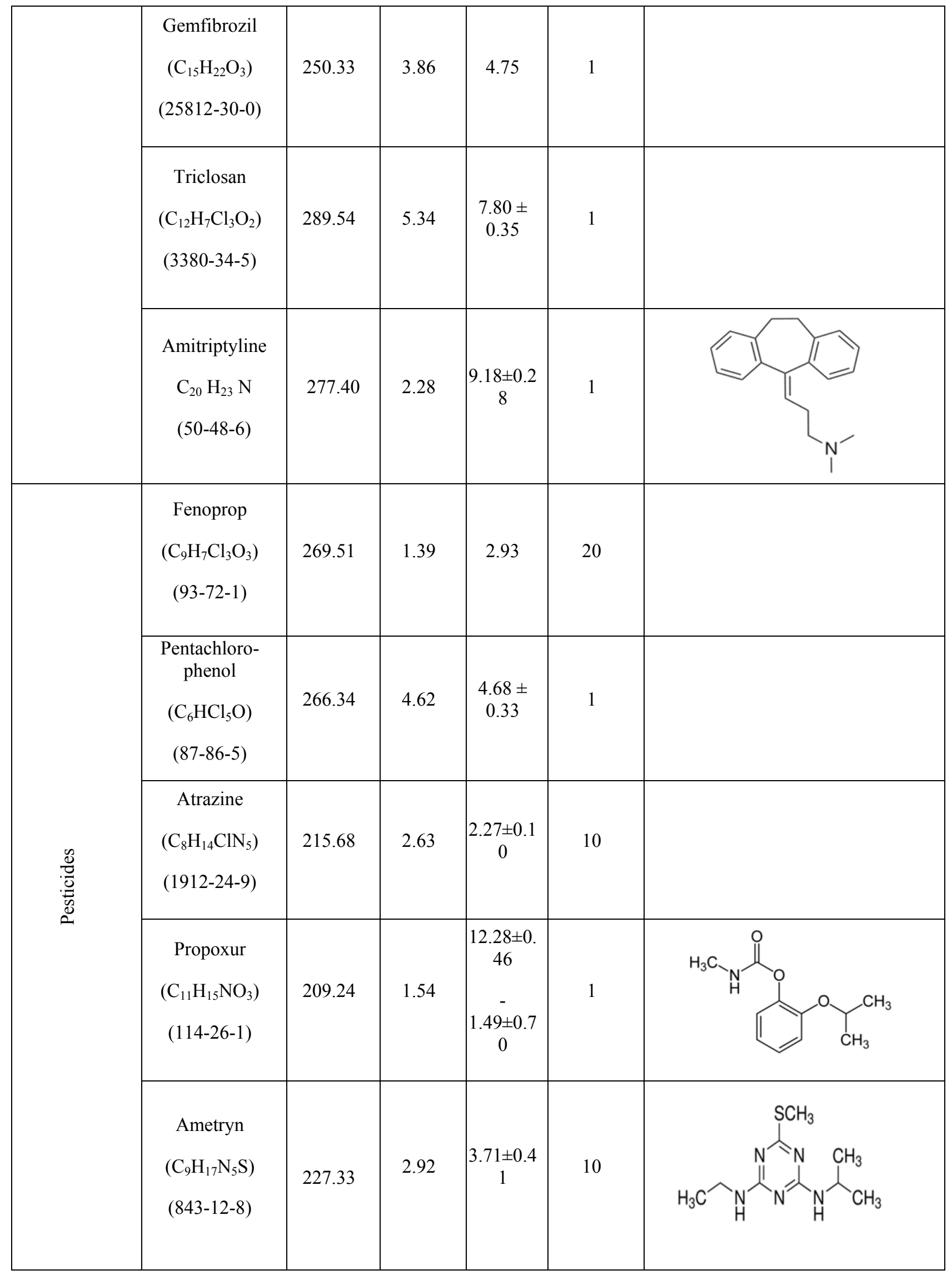




\begin{tabular}{|c|c|c|c|c|c|c|}
\hline & $\begin{array}{c}\text { Clofibric acid } \\
\text { (C10H11ClO3) } \\
(882-09-7)\end{array}$ & 214.65 & 0.61 & $\begin{array}{c}3.18 \\
\pm 0.10\end{array}$ & 1 & 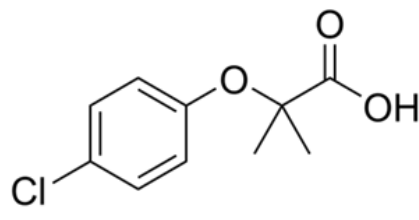 \\
\hline 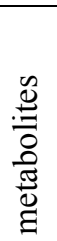 & $\begin{array}{c}\text { 4-tert- } \\
\text { butylphenol } \\
\left(\mathrm{C}_{10} \mathrm{H}_{14} \mathrm{O}\right) \\
(98-54-4)\end{array}$ & 150.22 & 3.40 & $\begin{array}{c}10.13 \pm \\
0.13\end{array}$ & 1 & \\
\hline 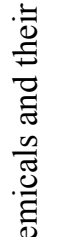 & $\begin{array}{c}\text { 4-tert- } \\
\text { octylphenol } \\
\left(\mathrm{C}_{14} \mathrm{H}_{22} \mathrm{O}\right) \\
(140-66-9) \\
\end{array}$ & 206.32 & 5.18 & $\begin{array}{c}10.15 \pm \\
0.15\end{array}$ & 1 & \\
\hline 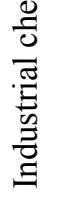 & $\begin{array}{c}\text { Bisphenol A } \\
\left(\mathrm{C}_{15} \mathrm{H}_{16} \mathrm{O}_{2}\right) \\
(80-05-7)\end{array}$ & 228.29 & 3.64 & $\begin{array}{c}10.29 \pm \\
0.10\end{array}$ & 1 & \\
\hline \multirow{4}{*}{ 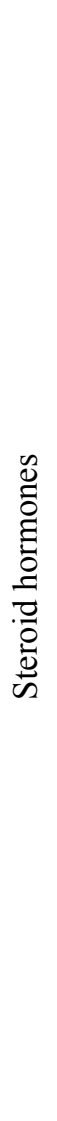 } & $\begin{array}{c}\text { Estrone } \\
\left(\mathrm{C}_{18} \mathrm{H}_{22} \mathrm{O}_{2}\right) \\
(53-16-7)\end{array}$ & 270.37 & 3.62 & $\begin{array}{c}10.25 \pm \\
0.40\end{array}$ & 5 & \\
\hline & $\begin{array}{c}\text { 17ß-Estradiol } \\
\left(\mathrm{C}_{18} \mathrm{H}_{24} \mathrm{O}_{2}\right) \\
(50-28-2)\end{array}$ & 272.38 & 4.15 & 10.27 & 5 & \\
\hline & $\begin{array}{c}\text { 17 } \beta \text {-Estradiol } \\
\text { 17-acetate } \\
\left(\mathrm{C}_{20} \mathrm{H}_{26} \mathrm{O}_{3}\right) \\
(1743-60-8)\end{array}$ & 314.42 & 5.11 & $\begin{array}{c}10.26 \pm \\
0.60\end{array}$ & 5 & \\
\hline & $\begin{array}{c}17-\alpha \\
\text { Ethinylestradiol } \\
\qquad\left(\mathrm{C}_{20} \mathrm{H}_{24} \mathrm{O}_{2}\right) \\
(57-63-6)\end{array}$ & 269.40 & 4.11 & $\begin{array}{c}10.24 \pm \\
0.60\end{array}$ & 10 & \\
\hline
\end{tabular}




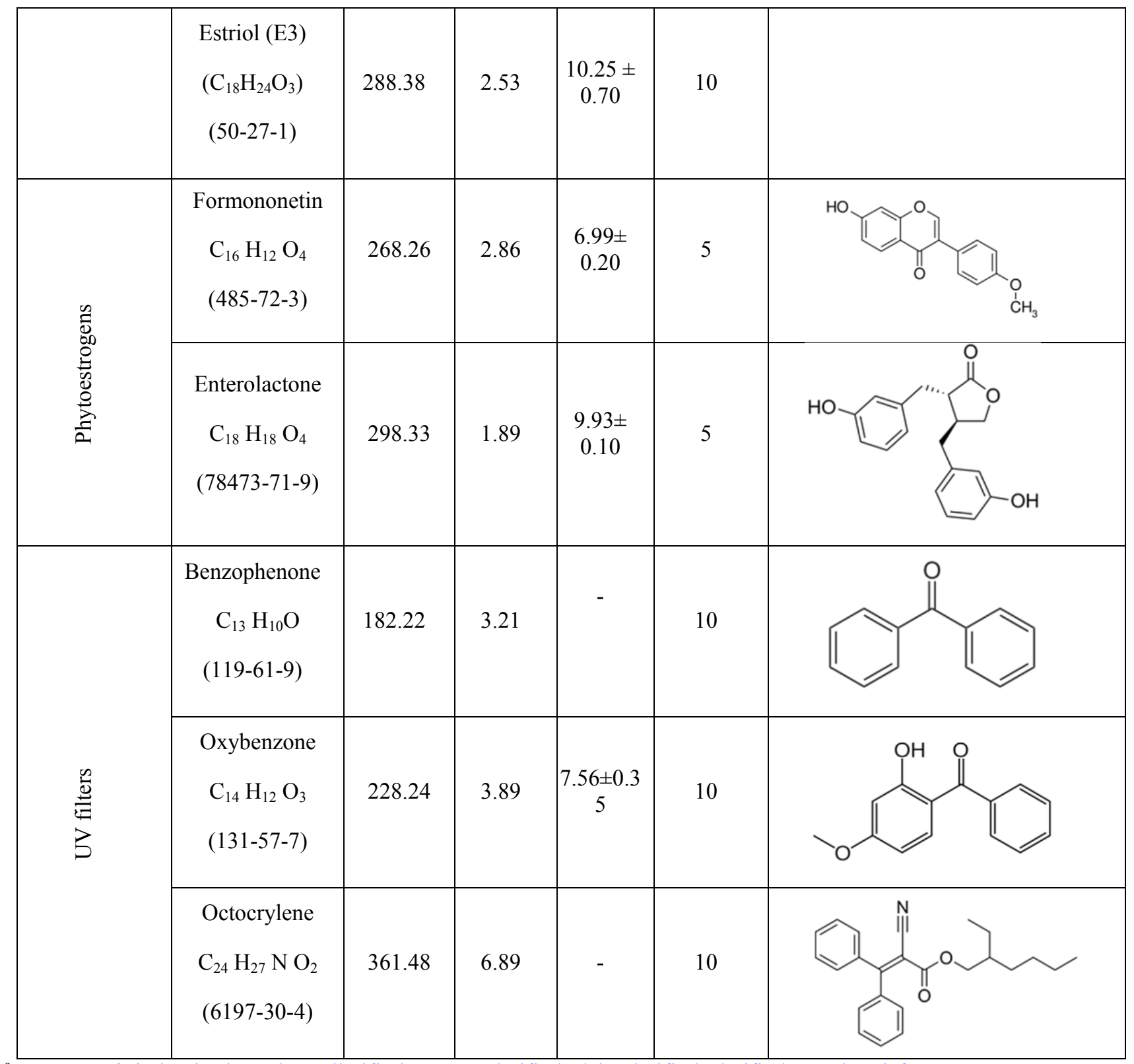

${ }^{a}$ Source: SciFinder database https://scifinder.cas.org/scifinder/view/scifinder/scifinderExplore.jsf

$\log D$ is $\operatorname{logarithm}$ of the distribution coefficient which is the ratio of the sum of concentrations of all forms of the compound (ionised and unionised) in octanol and water at a given $\mathrm{pH}$.

na: data not available

${ }^{b}$ Limit of detection (LOD) of the compounds during GC-MS analysis as described in Section 2.3. LOD is defined as the concentration of an analyte giving a signal to noise $(\mathrm{S} / \mathrm{N})$ ratio greater than 3 . The limit of reporting was determined using an $\mathrm{S} / \mathrm{N}$ ration of greater than 10. 
Table S2: Physicochemical properties of the selected mediators.

\begin{tabular}{|c|c|c|c|c|}
\hline Compounds & $\begin{array}{l}\text { Molecular } \\
\text { weight } \\
(\mathrm{g} / \mathrm{mol})\end{array}$ & $\begin{array}{l}\text { Molecular } \\
\text { formula } \\
\text { (CAS } \\
\text { number) } \\
\end{array}$ & $\begin{array}{c}\text { Dissociation } \\
\text { constant } \\
(\mathrm{pKa})^{\mathrm{a}}\end{array}$ & Chemical structure \\
\hline $\begin{array}{l}\text { 1-Hydroxybenzotriazole } \\
\text { (HBT) }\end{array}$ & 135.12 & $\begin{array}{c}\mathrm{C}_{6} \mathrm{H}_{5} \mathrm{~N}_{3} \mathrm{O} \\
(2592-95- \\
2)\end{array}$ & $\begin{array}{l}7.39 \pm 0.58 \\
0.48 \pm 0.30\end{array}$ & \\
\hline $\begin{array}{c}\text { Syringaldehyde } \\
\text { (SA) }\end{array}$ & 182.17 & $\begin{array}{c}\mathrm{C}_{9} \mathrm{H}_{10} \mathrm{O}_{4} \\
(134-96-3)\end{array}$ & $7.80 \pm 0.23$ & \\
\hline
\end{tabular}

${ }^{a}$ Source: SciFinder database https://scifinder.cas.org/scifinder/view/scifinder/scifinderExplore.jsf 
Table S3: Comparative degradation rates of TrOCs by different treatment options (based on removal over $24 \mathrm{~h}$ )

\begin{tabular}{|c|c|c|c|c|c|c|c|c|}
\hline \multirow{4}{*}{ Category } & \multirow{4}{*}{ Compounds } & \multicolumn{7}{|c|}{ TrOC degradation rate (ng/L.h) } \\
\hline & & Laccase & & case- HBT & & & Laccase-S & \\
\hline & & & HBT & centration $(\mathrm{m}$ & & & oncentration & $\mathrm{mM})$ \\
\hline & & & 0.1 & 0.5 & 1 & 0.1 & 0.5 & 1 \\
\hline \multirow{14}{*}{$\begin{array}{l}\frac{0}{0} \\
\frac{1}{0} \\
\frac{\pi}{2}\end{array}$} & Formononetin & 0.0 & 0.0 & 0.0 & 0.0 & $37.7 \pm 9.5$ & $25.4 \pm 4.0$ & $24.2 \pm 11.7$ \\
\hline & Salicylic acid & 0.0 & 0.0 & $66.2 \pm 12.2$ & $50.2 \pm 16$ & $10.4 \pm 8.3$ & $15.7 \pm 4.5$ & $15.2 \pm 3.0$ \\
\hline & Oxybenzone & 0.0 & $6.6 \pm 4.5$ & $80.1 \pm 16.7$ & $68.5 \pm 13.4$ & $72.0 \pm 5.4$ & $31.2 \pm 9.3$ & $56.7 \pm 11.2$ \\
\hline & Pentachlorophenol & $8.5 \pm 5.0$ & $19.9 \pm 1$ & $70.2 \pm 12.4$ & $67.8 \pm 11.7$ & $12.8 \pm 2.4$ & $9.7 \pm 1.5$ & $31.7 \pm 1.4$ \\
\hline & Enterolactone & $16.1 \pm 5.7$ & $61.0 \pm 31.2$ & $69.8 \pm 18.8$ & $78.8 \pm 12.8$ & $48.8 \pm 16.0$ & $50.6 \pm 12.3$ & $63.1 \pm 18.0$ \\
\hline & Triclosan & $62.5 \pm 18.7$ & $90.6 \pm 14.7$ & $91.8 \pm 13.3$ & $71.6 \pm 15.4$ & $85.8 \pm 4.0$ & $84.7 \pm 2.7$ & $84.8 \pm 3.0$ \\
\hline & 4-tert-Butylphenol & $62.2 \pm 11.4$ & $68.2 \pm 14.2$ & $65.8 \pm 15.6$ & $60.0 \pm 13.6$ & $51.6 \pm 0.9$ & $51.7 \pm 0.5$ & $51.5 \pm 0.6$ \\
\hline & 4-tert-Octylphenol & $59.2 \pm 13.2$ & $61.5 \pm 12.4$ & $62.3 \pm 17.0$ & $67.5 \pm 16.2$ & $67.2 \pm 5.2$ & $67.2 \pm 8.5$ & $67.2 \pm 3.0$ \\
\hline & $17 \beta$-Estradiol 17 -acetate & $83.1 \pm 17.9$ & $84.1 \pm 2.6$ & $84.9 \pm 11.0$ & $86.7 \pm 5.6$ & $92.6 \pm 3.8$ & $93.0 \pm 4.0$ & $91.8 \pm 2.8$ \\
\hline & Estriol & $99.0 \pm 5.6$ & $99.6 \pm 8.3$ & $98.8 \pm 5.2$ & $93.6 \pm 3.5$ & $83.6 \pm 4.5$ & $86.7 \pm 3.7$ & $81.7 \pm 2.3$ \\
\hline & Bisphenol A & $96.7 \pm 3.6$ & $99.3 \pm 4.5$ & $98.3 \pm 3.5$ & $96.1 \pm 2.6$ & $98.5 \pm 2.8$ & $98.5 \pm 3.7$ & $98.2 \pm 2.5$ \\
\hline & $17 \beta$-Estradiol & $99.0 \pm 2.4$ & $100.5 \pm 2.8$ & $101.2 \pm 2.3$ & $105.2 \pm 3.0$ & $98.4 \pm 2.6$ & $100.1 \pm 3.5$ & $99.2 \pm 2.4$ \\
\hline & $17 \alpha$ - Ethinylestradiol & $91.9 \pm 2.4$ & $92.0 \pm 2.6$ & $93.5 \pm 1.8$ & $91.6 \pm 2.4$ & $77.4 \pm 1.3$ & $78.2 \pm 1.4$ & $75.3 \pm 1.8$ \\
\hline & Estrone & $104.0 \pm 17.5$ & $105.4 \pm 18.6$ & $106.3 \pm 13.6$ & $106.0 \pm 7.2$ & $107.9 \pm 6.6$ & $108.5 \pm 6.3$ & $108.5 \pm 5.6$ \\
\hline \multirow{16}{*}{$\begin{array}{l}: 0 \\
0 \\
0 \\
0 \\
0 \\
0 \\
0 \\
0 \\
0 \\
z\end{array}$} & Benzophenone & 0.0 & 0.0 & 0.0 & 0.0 & 0.0 & 0.0 & 0.0 \\
\hline & Ketoprofen & 0.0 & $1.5 \pm 2.8$ & $2.5 \pm 3.6$ & $7.8 \pm 2.8$ & 0.0 & 0.0 & 0.0 \\
\hline & Primidone & 0.0 & 0.0 & 0.0 & $29.2 \pm 3.8$ & $16.7 \pm 28.0$ & 0.0 & 0.0 \\
\hline & Atrazine & 0.0 & $43.2 \pm 15.8$ & $69.1 \pm 16.0$ & $53.8 \pm 13.9$ & $23.9 \pm 10.1$ & $25.6 \pm 4.1$ & $51.2 \pm 6.4$ \\
\hline & Ibuprofen & 0.0 & 0.0 & 0.0 & 0.0 & $10.9 \pm 1.0$ & $2.0 \pm 5.2$ & $0.9 \pm 1.8$ \\
\hline & Amitriptyline & $2.8 \pm 1.3$ & $4.3 \pm 1.6$ & $24.8 \pm 4.8$ & $18.2 \pm 3.4$ & $18.9 \pm 7.4$ & $7.4 \pm 2.4$ & $34.8 \pm 12.0$ \\
\hline & Carbamazepine & $3.9 \pm 10.6$ & 0.0 & $3.0 \pm 11.7$ & 0.0 & 0.0 & 0.0 & 0.0 \\
\hline & Propoxur & $5.5 \pm 2.8$ & $5.5 \pm 2.3$ & $6.5 \pm 9.2$ & $8.8 \pm 11.7$ & 0.0 & 0.0 & 0.0 \\
\hline & Clofibric acid & $6.2 \pm 4.0$ & $8.0 \pm 3.5$ & $17.3 \pm 9.6$ & $10.4 \pm 4.7$ & $16.4 \pm 4.2$ & $14.2 \pm 8.7$ & $22.3 \pm 14.1$ \\
\hline & Fenoprop & $8.2 \pm 1.3$ & $13.8 \pm 4.8$ & $17.9 \pm 3.5$ & $18.6 \pm 1.7$ & $3.2 \pm 12.8$ & $4.6 \pm 15.4$ & $3.7 \pm 13.5$ \\
\hline & Metronidazole & $2.6 \pm 0.8$ & $3.3 \pm 0.8$ & $6.3 \pm 1.1$ & $8.7 \pm 0.5$ & $7.9 \pm 1.2$ & $1.2 \pm 4.5$ & $1.0 \pm 4.7$ \\
\hline & Octocrylene & $13.9 \pm 26.8$ & $1.1 \pm 2.3$ & $1.4 \pm 2.8$ & $1.9 \pm 0.7$ & $34.4 \pm 14.5$ & $16.3 \pm 7.5$ & $53.3 \pm 9.8$ \\
\hline & Gemfibrozil & $18.0 \pm 7.0$ & $19.8 \pm 12.0$ & $32.6 \pm 14.4$ & $13.8 \pm 5.4$ & $12.8 \pm 6.4$ & $4.0 \pm 4.5$ & $6.6 \pm 2.8$ \\
\hline & Naproxen & $19.0 \pm 14.3$ & $59.6 \pm 9.0$ & $95.6 \pm 15.1$ & $81.8 \pm 12.4$ & $12.1 \pm 6.2$ & $10.6 \pm 0.8$ & $57.6 \pm 6.3$ \\
\hline & Ametryn & $24.0 \pm 8.1$ & $18.7 \pm 5.3$ & $29.0 \pm 9.4$ & $23.5 \pm 4.3$ & $24.4 \pm 5.1$ & $25.3 \pm 2.8$ & $19.0 \pm 2.4$ \\
\hline & Diclofenac & $62.0 \pm 17.3$ & $57.0 \pm 12.5$ & $79.7 \pm 14.5$ & $70.1 \pm 11.6$ & $72.0 \pm 16.5$ & $85.6 \pm 2.1$ & $74.3 \pm 13.2$ \\
\hline
\end{tabular}




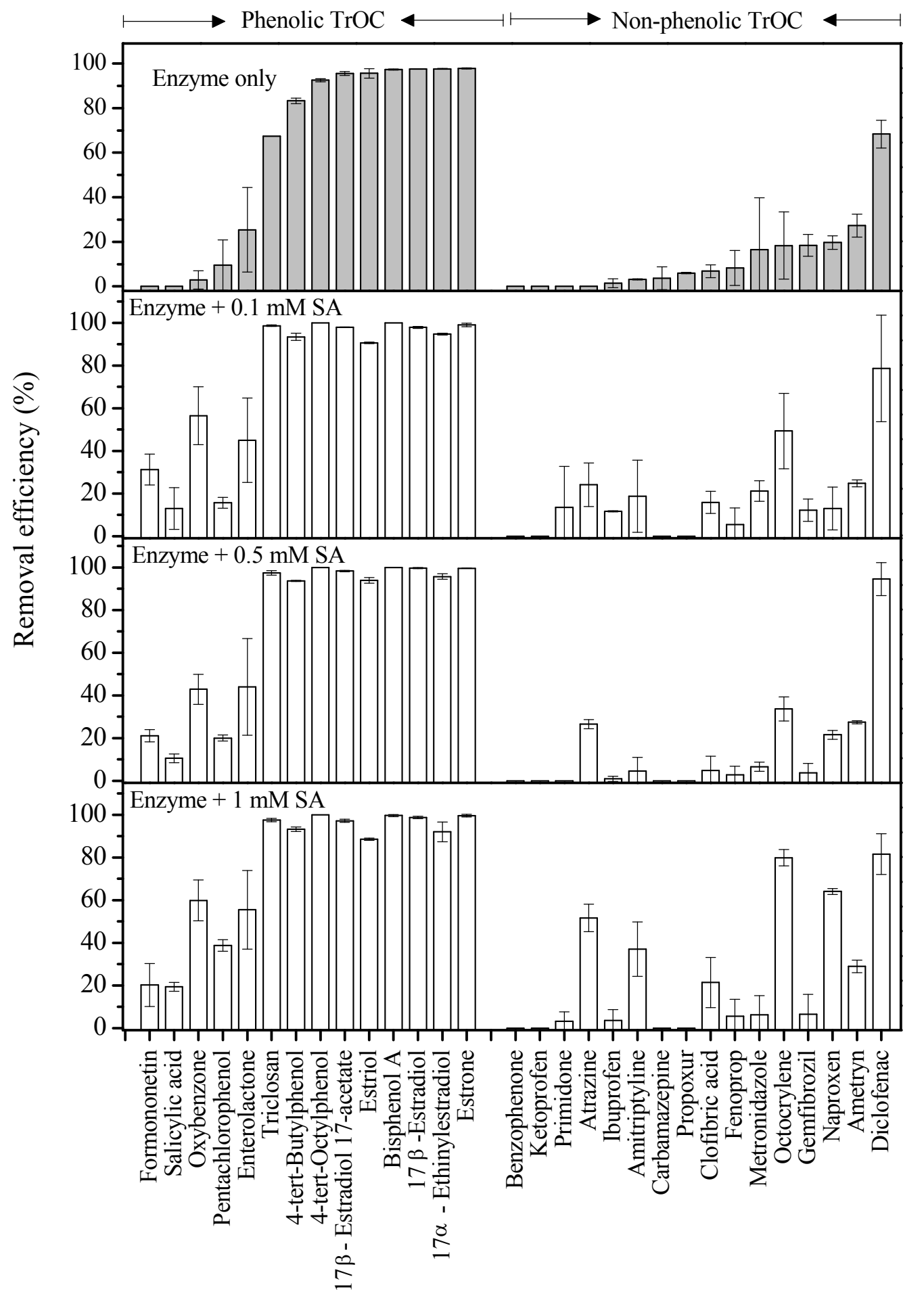


Figure S4: Removal of 30 TrOC by crude enzyme extract from T. versicolor (ATCC 7731) in the absence and presence of SA at concentrations of $0.1,0.5$, and $1 \mathrm{mM}$. The error bars represent the standard deviation of three replicates. 


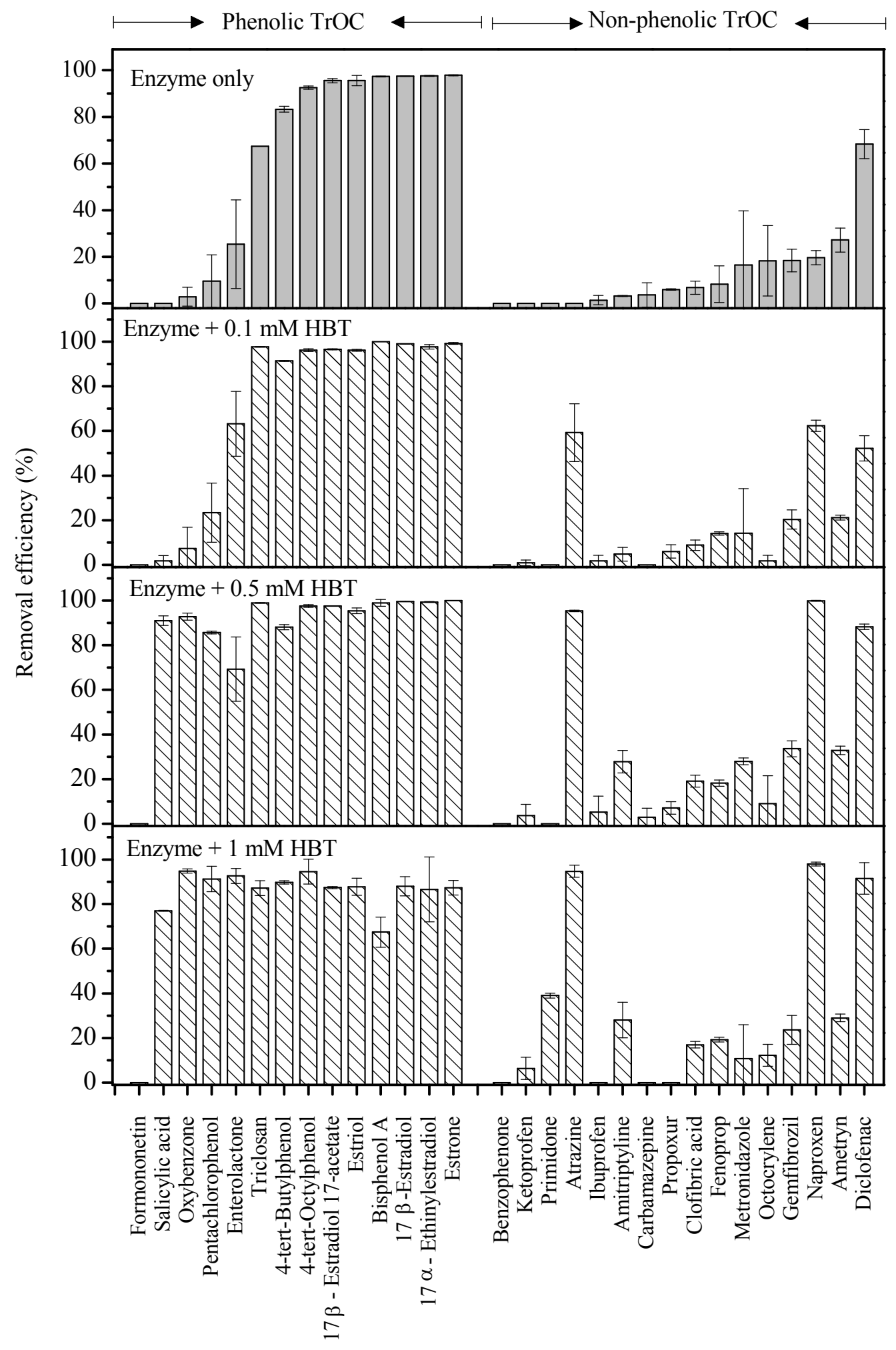


Figure S5: Removal of 30 TrOC by crude enzyme extract from T. versicolor (ATCC 7731) in the absence and presence of HBT at concentrations of $0.1,0.5$, and $1 \mathrm{mM}$. The error bars represent the standard deviation of three replicates. 